\title{
Biochar Mediated-Alleviation of Chromium Stress and Growth Improvement of Different Maize Cultivars in Tannery Polluted Soils
}

\author{
Muhammad Asaad Bashir ${ }^{1}\left(\mathbb{D}\right.$, , Xiukang Wang $^{2, *}$, Muhammad Naveed ${ }^{3, * \mathbb{D}}$, Adnan Mustafa ${ }^{4}$, , Sobia Ashraf ${ }^{3}$, \\ Tayyaba Samreen $^{3}$, Sajid Mahmood Nadeem ${ }^{5}$ and Moazzam Jamil ${ }^{1}$
}

check for updates

Citation: Asaad Bashir, M.; Wang, X.; Naveed, M.; Mustafa, A.; Ashraf, S.; Samreen, T.; Nadeem, S.M.; Jamil, M. Biochar Mediated-Alleviation of Chromium Stress and Growth Improvement of Different Maize Cultivars in Tannery Polluted Soils. Int. J. Environ. Res. Public Health 2021, 18, 4461. https://doi.org/10.3390/ ijerph18094461

Academic Editor: Yuping Qiu

Received: 19 March 2021

Accepted: 19 April 2021

Published: 22 April 2021

Publisher's Note: MDPI stays neutra with regard to jurisdictional claims in published maps and institutional affiliations.

Copyright: (c) 2021 by the authors. Licensee MDPI, Basel, Switzerland. This article is an open access article distributed under the terms and conditions of the Creative Commons Attribution (CC BY) license (https:/ / creativecommons.org/licenses/by/ $4.0 /$ )
1 Department of Soil Science, Faculty of Agriculture and Environment, The Islamia University of Bahawalpur, Bahawalpur 63100, Pakistan; m.asaadbashir@gmail.com (M.A.B.); moazzam.jamil@iub.edu.pk (M.J.)

2 College of Life Sciences, Yan'an University, Yan'an 716000, China

3 Institute of Soil and Environmental Sciences, University of Agriculture, Faisalabad 38040, Pakistan; sobiaashraf13@googlemail.com (S.A.); tybasamreen@gmail.com (T.S.)

4 Biology Centre, SOWA RI, Czech Academy of Sciences, 37005 Ceske Budejovice, Czech Republic; adnanmustafa780@gmail.com or adnan.mustafa@bc.cas.cz

5 Burewala Sub-Campus, University of Agriculture Faisalabad, Vehari 61100, Pakistan; sajidmn92@hotmail.com

* Correspondence: wangxiukang@yau.edu.cn (X.W.); muhammad.naveed@uaf.edu.pk (M.N.)

\begin{abstract}
Soil pollution with heavy metal is a serious problem across the globe and is on the rise due to the current intensification of chemical industry. The leather industry is one of them, discharging chromium (Cr) in huge quantities during the process of leather tanning and polluting the nearby land and water resources, resulting in deterioration of plant growth. In this study, the effects of biochar application at the rate of 3\% were studied on four maize cultivars, namely NK-8441, P-1543, NK-8711, and FH-985, grown in two different tannery polluted Kasur (K) and Sialkot (S) soils. Maize plants were harvested at vegetative growth and results showed that $\mathrm{Cr}$ toxicity adversely not only affected their growth, physiology, and biochemistry, but also accumulated in their tissues. However, the level of $\mathrm{Cr}$ toxicity, accumulation, and its influence on maize cultivars varied greatly in both soils. In this pot experiment, biochar application played a crucial role in lessening the Cr toxicity level, resulting in significant increase in plant height, biomass (fresh and dry), leaf area, chlorophyll pigments, photosynthesis, and relative water content (RWC) over treatment set as a control. However, applied biochar significantly decreased the electrolyte leakage (EL), antioxidant enzymes, lipid peroxidation, proline content, soluble sugars, and available fraction of $\mathrm{Cr}$ in soil as well as $\mathrm{Cr}$ (VI and III) concentration in root and shoot tissues of maize plant. In addition to this, maize cultivar differences were also found in relation to their tolerance to $\mathrm{Cr}$ toxicity and cultivar P-1543 performed better over other cultivars in both soils. In conclusion, biochar application in tannery polluted soils could be an efficient ecofriendly approach to reduce the $\mathrm{Cr}$ toxicity and to promote plant health and growth.
\end{abstract}

Keywords: chromium toxicity; biochar; maize; tannery polluted soils; antioxidant enzymes; Kasur and Sialkot; tannery polluted soils

\section{Introduction}

Soil contamination with heavy metals is an increasingly prominent issue worldwide and is growing due to the use of heavy metal-loaded materials in industries. The untreated waste products of industries contain high concentrations of toxic heavy metal, and thus, induce environmental health risks due to their persistence in nature and tendency to accumulate in food; hence, they cause severe human health hazards [1]. A significant amount of industrial effluent loaded with heavy metal is being discharged into the environment, resulting in increased agricultural soil contamination annually [2,3]. In Pakistan, the leather tanning processes are the largest contributors of soil contamination with chromium 
(Cr) [4-6]. More than 800 tanning units are present on eastern fringe (Kasur and Sialkot) of Pakistan due to the abundance of water, easily available labor, and inexpensive cost of materials [7]. However, improper waste management of this industry and discharge of effluent without any treatment is a major cause of soil contamination [8].

Chromium is the most commonly used heavy metal in the leather industry during tanning processes [9] and is usually discharged with wastewater by repeated (3-4 times) tanning sessions [10]. Chromium, even at low concentrations, is toxic to plants as well as animals [11-13]. Cr toxicity evokes considerable stress symptoms in plants, i.e., alterations in the germination process, reduced photosynthesis, and disturbance in nutrient uptake, which affects plant growth, crop yield, and total dry matter production $[12,14,15]$. Chromium also results in harmful effects of osmotic balance and metabolic activities by damaging the plant cell membrane that leads to electrolyte leakage (EL) and lipid peroxidation [16]. Moreover, $\mathrm{Cr}$ toxicity induces oxidative stress in plants by forming reactive oxygen species (ROS) that damages the cell molecules and impairs the antioxidant system $[17,18]$. Through the food chain, acute exposure of $\mathrm{Cr}$ in humans causes severe health problems, such as gastrointestinal, respiratory, cardiovascular, neurological, immunological, reproductive, and developmental problems [4,19]. In addition, a more destructive effect of $\mathrm{Cr}$ is the induction of various types of cancers, including lung, skin, kidney, and bladder [20-22].

It should be acknowledged that the toxicity of $\mathrm{Cr}$ depends upon its valence state. Naturally, $\mathrm{Cr}$ is found in multiple oxidation states in the range of -2 to $+6[23,24]$, but $\mathrm{Cr}$ (VI) and Cr (III) dominate in the environment [25,26]. Chromium (III) is relatively harmless, less soluble/mobile, and naturally present in stable form [27,28]. Conversely, $\mathrm{Cr}$ (VI) is considered to be highly toxic, soluble/mobile, and causes severe health risks $[29,30]$. Chromium (VI) rarely occurs in nature and is usually the product of anthropogenic activities [31]. In the tannery industry, predominantly $\mathrm{Cr}$ (III) is released through wastewater effluent $[9,15]$. Here, redox reaction performs very important role in the interconversion of most dominant species of $\mathrm{Cr}$, i.e., $\mathrm{Cr}$ (III) and $\mathrm{Cr}$ (VI) [30]. Toxicity caused by the presence of large amount of $\mathrm{Cr}$ in tannery waste polluted soils could consequence in the absence of vegetation cover [32]. Therefore, organic amendments (manure, biosolids, compost, biochar, etc.) are generally used to enhance soil health and crop growth due to their valuable effects on soil fertility by enhancing soil aggregation, soil aggregate stability, and other physico-chemical characteristics of soil [33-35].

Biochar is a recalcitrant fine-grained porous organic substance produced by pyrolysis of biomass in oxygen limited conditions [32,36]. It improves soil organic matter (SOM) and water holding capacity, reduces the nutrient loss, plays an important role in metal sorption [37-40] including heavy metals and stimulates the microbial activity of soil [32,41]. It has comparatively extensive surface area with high degree of porosity and structured carbon matrix [42] which acts as a pollutant sorbent [43]. It can make precipitates of $\mathrm{Cr}$ by reacting with various mineral components (oxidates, carbonates, or phosphates) $[44,45]$. Numerous oxygen containing acidic (carbonyl, carboxylic, hydroxyl, lactone, phenol, etc.) and basic (chromene, ketone, pyrone, etc.) functional groups may also be present in biochar, which binds metals through complexation $[39,46,47]$. Moreover, biochar could enhance supply of proton to reduce $\mathrm{Cr}$ (VI) into its less toxic $\mathrm{Cr}$ (III) form [47-49]. Many researchers have previously described the biochar potential to improve the soil characteristics and nutrient uptake by plants, especially under pollutant stress conditions [50-52]. Only a limited literature is available on physiological as well as biochemical responses of maize cultivars to biochar applied in soil polluted with indigenous tannery waste $[12,47,53]$.

Therefore, we hypothesized that biochar may reduce the toxicity of $\mathrm{Cr}$ (VI) by reducing it into its less toxic form, i.e., $\mathrm{Cr}$ (III) and decrease its accumulation in plants. Hence, keeping in view the impact of biochar application in promoting soil characteristics along with the removal of toxic pollutants, a pot study was designed to assess the $\mathrm{Cr}$ availability and potential transfer to maize cultivars in tannery polluted soils collected from two districts (Kasur and Sialkot) of Punjab, Pakistan. 


\section{Materials and Methods}

\subsection{Production of Biochar and Its Characterization}

Air and oven dried $\left(50^{\circ} \mathrm{C}\right)$ sugarcane bagasse (SB) with $10-15 \%$ moisture content was used as feedstock to produce biochar. The increase in muffle furnace temperature was $8-10{ }^{\circ} \mathrm{C} \mathrm{min}-1$, which was maintained at a residence time of $20 \mathrm{~min}$ on attaining $350{ }^{\circ} \mathrm{C}$ temperature [54].

The physical parameters of SB biochar were measured by using a suspension ratio of 1:20 $(w / v)$ prepared in deionized water after shaking on a mechanical shaker for one and a half hours [55].

The ammonium acetate compulsory displacement method [56], with little modification, was used to determine cation exchange capacity (CEC) of biochar (Table 1).

Table 1. Physico-chemical characteristics and elemental composition of biochar.

\begin{tabular}{lcc}
\hline Physicochemical Characteristics & Unit & Biochar (SB) \\
\hline $\mathrm{pH}(1: 20)$ & & $6.49 \pm 0.04$ \\
Electrical conductivity (EC) (1:20) & $\mathrm{dS} \mathrm{m}^{-1}$ & $1.59 \pm 0.03$ \\
Cation exchange capacity (CEC) & $\mathrm{Cmol}_{\mathrm{c}} \mathrm{kg}^{-1}$ & $86.90 \pm 1.60$ \\
Moisture & $\%$ & $3.36 \pm 0.19$ \\
Volatile matter & $\%$ & $17.32 \pm 0.64$ \\
Ash content & $\%$ & $21.82 \pm 0.44$ \\
Fixed carbon & $\%$ & $57.50 \pm 1.50$ \\
Conversion efficiency (yield) & $\%$ & $51.61 \pm 0.13$ \\
Surface area & $\mathrm{m}^{2} \mathrm{~g}^{-1}$ & $84.16 \pm 2.11$ \\
Nutritional Composition & & \\
Carbon (C) & $\%$ & $54.81 \pm 0.40$ \\
Hydrogen (H) & $\%$ & $2.56 \pm 0.13$ \\
Oxygen (O) & $\%$ & $19.92 \pm 1.70$ \\
Nitrogen (N) & $\%$ & $1.89 \pm 0.01$ \\
Phosphorus (P) & $\mathrm{g} \mathrm{kg}^{-1}$ & $3.34 \pm 0.62$ \\
Potassium (K) & $\mathrm{g} \mathrm{kg}^{-1}$ & $2.13 \pm 0.48$ \\
Calcium (Ca) & $\mathrm{g} \mathrm{kg}^{-1}$ & $2.01 \pm 0.26$ \\
Magnesium (Mg) & $\mathrm{g} \mathrm{kg}^{-1}$ & $7.86 \pm 1.24$ \\
Zinc (Zn) & $\mathrm{mg} \mathrm{kg}^{-1}$ & $84.52 \pm 4.27$ \\
Iron (Fe) & $\mathrm{mg} \mathrm{kg}^{-1}$ & $88.36 \pm 3.38$ \\
Manganese (Mn) & $\mathrm{mg} \mathrm{kg}^{-1}$ & $81.54 \pm 1.84$ \\
Total Chromium (Cr) & $\mu \mathrm{mg} \mathrm{kg}^{-1}$ & $0.06 \pm 0.03$ \\
\hline The values are mean \pm standard error (S.E.) $(\mathrm{n}=3)$ & &
\end{tabular}

The values are mean \pm standard error (S.E.) $(n=3)$.

The moisture content (\%) of biochar was measured through the difference method by calculating the fresh and dry (dried in an oven at $65^{\circ} \mathrm{C}$ ) weight:

$$
\text { Moisture content }(\%)=\frac{\text { Fresh weight }- \text { Dry weight }}{\text { Dry weight }} \times 100
$$

The volatile matter content (\%) of biochar was calculated as the weight loss after combustion in a ceramic crucible with a loose ceramic cap at $850-900{ }^{\circ} \mathrm{C}(6 \mathrm{~min})$.

The ash content (\%) of biochar was estimated by the heating of biochar in a muffle furnace at $200{ }^{\circ} \mathrm{C}$ for $1 \mathrm{~h}$ and then at $750{ }^{\circ} \mathrm{C}$ for an additional $4 \mathrm{~h}$ with no ceramic cap [57]:

$$
\text { Ash content }(\%)=\frac{\text { Weight of ash }}{\text { Weight of biochar }} \times 100
$$

The fixed carbon content (\%) was measured by difference method after measuring the moisture, volatile matter, and ash content [46]:

$$
\text { Fixed carbon }(\%)=100-(\text { Moisture }+ \text { Volatile matter }+ \text { Ash }) \%
$$


The conversion efficiency (yield) of biochar was measured by using the following equation:

$$
\text { Conversion efficiency }(\%)=\frac{\text { Weight of biochar }}{\text { Weight of feedstock }} \times 100
$$

A surface area analyzer (NOVA 1200; Quantachrome Instruments, Boynton Beach, FL, USA) was used for determining the surface area and pore volume of biochar according to Brunauer-Emmett-Teller (BET) (EMSL Analytical, New York, NY, USA) nitrogen adsorption method at 77 Kelvin [58].

The detection of major elements, i.e., carbon $(\mathrm{C})$, hydrogen $(\mathrm{H})$, and nitrogen $(\mathrm{N})$ was carried out at high-temperature catalyzed combustion through a $\mathrm{CHN}$ elemental analyzer (Carlo-Erba NA-1500) (SPW Industrial, Laguna Hills, CA, USA) and resulting $\mathrm{CO}_{2}, \mathrm{H}_{2}$, and $\mathrm{NO}_{2}$ gases were detected by using infrared technique.

Difference method was used for the determination of oxygen $(\mathrm{O})$ :

$$
\text { Oxygen }(\%)=100-(\text { Ash }+ \text { carbon }+ \text { hydrogen }+ \text { nitrogen }) \%
$$

The dry-ashing method with little modification was used to measure macronutrients, i.e., phosphorus $(\mathrm{P})$, potassium $(\mathrm{K})$, calcium $(\mathrm{Ca})$, and magnesium $(\mathrm{Mg})$ as well as micronutrients, i.e., iron $(\mathrm{Fe})$, zinc $(\mathrm{Zn})$, copper $(\mathrm{Cu})$, and manganese $(\mathrm{Mn})$ in biochar samples [59]. Therefore, biochar samples were ashed for $8 \mathrm{~h}$ in a muffle furnace (Gallonhop, England, $\mathrm{UK})$ and then $\mathrm{HNO}_{3}(5 \mathrm{~mL})$ was added to each vessel and heated $\left(120^{\circ} \mathrm{C}\right)$ on a hot plate until dry. Upon cooling, $\mathrm{HNO}_{3}(1 \mathrm{~mL})$ and $\mathrm{H}_{2} \mathrm{O}_{2}(4 \mathrm{~mL})$ was added, and samples were again heated $\left(120^{\circ} \mathrm{C}\right)$ by placing them back on a preheated plate, until dry, and then solubilized and filtered. Inductively coupled plasma with optical emission spectroscopy (ICP-OES) (Perkin Elmer Optima 2100 DV) (PerkinElmer, Massachusetts, USA) was used for nutrient analysis.

\subsection{Collection and Analysis of Tannery Polluted Soil Samples}

Tannery polluted soil samples were collected from the vicinity of tanning industry of two districts of Punjab, Kasur (K) and Sialkot (S). These soil samples after sieving were subjected to various physico-chemical analysis (Table 2). Electrical conductivity (EC) meter was used to measure EC of the extract of the saturated soil paste. The texture of soil was determined by the hydrometer method [60]. Soil organic carbon was estimated by a TRL-TOC model analyzer (TRL Instruments ${ }^{\circledR}$ 1328. Cadde, Demirag Apt. No: 14/5, Ankara, Turkey). Soil CEC was determined by following the method of Sumner et al. [61] and calcium carbonate was measured by following the method of Leoppert et al. [62]. Soil total $\mathrm{N}$ was determined by the Kjeldahl method [63], available P with sodium bicarbonate [64], and extractable $\mathrm{K}$ by the method detailed in Richards [65]. Atomic adsorption spectrophotometer (Perkin Elmer Aanalyst-100, USA) was used for the total $\mathrm{Cr}$ concentration (Cr III and VI) after aqua regia $\left(\left(\mathrm{HCl}: \mathrm{HNO}_{3}=3: 1\right)\right.$ digestion of the soil samples [66]. The chromium (VI) concentration in soil was measured by using 1,5-diphenylcarbazide following the DTPA method [67] with modifications [68] at $540 \mathrm{~nm}$ wavelength using spectrophotometer (Shimadzu UV-1800) and Cr (III) was determined by subtracting the concentrations of $\mathrm{Cr}$ (VI) from total Cr. 
Table 2. Physico-chemical characterization of tannery polluted Kasur (K) and Sialkot (S) soils.

\begin{tabular}{lccc}
\hline Parameters & Unit & K Soil & S Soil \\
\hline Organic carbon $(\mathrm{OC})$ & $\mathrm{g} \mathrm{kg}^{-1}$ & $3.41 \pm 0.52$ & $4.16 \pm 0.64$ \\
Calcium carbonate $\left(\mathrm{CaCO}_{3}\right)$ & $\%$ & $2.96 \pm 0.54$ & $3.23 \pm 0.49$ \\
Soil texture & - & Silty loam & Silty clay loam \\
$\mathrm{pH}$ & - & $7.75 \pm 0.81$ & $7.91 \pm 0.89$ \\
Electrical conductivity (EC) & $\mathrm{dS} \mathrm{m}^{-1}$ & $1.469 \pm 0.02$ & $1.969 \pm 0.01$ \\
Cation exchange capacity (CEC) & $\mathrm{cmol}_{\mathrm{c}} \mathrm{kg}^{-1}$ & $11.56 \pm 1.38$ & $15.72 \pm 1.42$ \\
Total nitrogen (N) & $\%$ & $0.054 \pm 0.01$ & $0.061 \pm 0.01$ \\
Available phosphorus (P) & $\mathrm{mg} \mathrm{kg}^{-1}$ & $5.46 \pm 0.67$ & $7.53 \pm 0.82$ \\
Extractable potassium (K) & $\mathrm{mg} \mathrm{kg}^{-1}$ & $94.0 \pm 3.38$ & $112.0 \pm 4.31$ \\
Cr (VI) & $\mathrm{mg} \mathrm{kg}^{-1}$ & $12.45 \pm 1.02$ & $18.62 \pm 1.29$ \\
Cr (III) & $\mathrm{mg} \mathrm{kg}^{-1}$ & $40.02 \pm 2.03$ & $54.94 \pm 2.30$ \\
Total Cr & $\mathrm{mg} \mathrm{kg}^{-1}$ & $52.47 \pm 2.14$ & $73.56 \pm 2.43$ \\
\hline
\end{tabular}

The values are mean \pm S.E. $(\mathrm{n}=3)$; K: Kasur soil; S: Sialkot soil.

\subsection{Experimental Design and Setup}

A pot experiment, comprising 16 different treatments in triplicates by applying SB biochar at a rate of $3 \%(w / w)$ in the tannery polluted soils of $\mathrm{K}$ and $\mathrm{S}$, using four different maize cultivars (NK-8441, P-1543, NK-8711, and FH-985) was performed. The arrangement of the experiment was according to a completely randomized design (CRD). Pots were filled with sieved soil $(6 \mathrm{~kg})$ and the recommended dose of $\mathrm{N}\left(180 \mathrm{Kg} \mathrm{ha}^{-1}\right), \mathrm{P}\left(120 \mathrm{Kg} \mathrm{ha}^{-1}\right)$, and $\mathrm{K}\left(90 \mathrm{Kg} \mathrm{ha}^{-1}\right)$ fertilizers was also applied to fulfill the initial nutrient requirements of maize plants by using urea, diammonium phosphate, and sulfate of potash, respectively. The arrangement of the experiment was with three replicates. Five seeds of selected maize cultivars were sown, and seven days after emergence, thinning was done to two plants per pots.

\subsection{Measuring Growth Parameters}

At vegetative growth (45 days), plants were harvested and roots/shoots length of maize plant was recorded by using meter rod. Plant fresh and dry weight (after oven drying at $65^{\circ} \mathrm{C}$ for $72 \mathrm{~h}$ ) of maize root/shoot part was determined by using a weighing balance. To calculate the leaf area $(\mathrm{Y})$ of maize cultivars, the following equation was used, which was earlier described by Chanda and Singh [69]:

$$
\text { Leaf area }(Y)=\text { Length } \times \text { Width } \times 0.75
$$

\subsection{Measuring Maize Physiological Characteristics}

\subsubsection{Physiological Parameters}

For photosynthetic pigments and gaseous exchange measurements, the fully matured top second maize leaf from each treatment was collected. SPAD (soil plant analysis development) chlorophyll content was measured with the help of SPAD-502 m (Konica-Minolta, Tokyo, Japan). Chlorophyll (a and b) and total carotenoid contents were also analyzed by the weighing of fresh leaves $(0.5 \mathrm{~g})$ and homogenized with $80 \%$ acetone $(10 \mathrm{~mL})$. The extracts were centrifuged $\left(10,000 \mathrm{rpm}\right.$ for $15 \mathrm{~min}$ at $\left.4{ }^{\circ} \mathrm{C}\right)$ and absorbance of the supernatant was measured at 645,663 , and $480 \mathrm{~nm}$ by using a spectrophotometer (Shimadzu UV-1800) [70].

The CIRAS-3 portable photosynthesis system was used for gaseous exchange measurements, such as transpiration rate (E), plant photosynthetic rate (A), stomatal conductance (gs), etc. (portable photosynthesis system, Amesbury, MA, USA). 


\subsubsection{Water Relations of Plants}

Water relations of maize plants in terms of relative water contents (RWC) and electrolyte leakage (EL) were determined. The RWC of plant leaf $\left(1 \mathrm{~cm}^{2}\right)$ was determined by using the following formula [71]:

$$
\text { Relative water content }(\%)=\frac{\text { Fresh Weight }- \text { Dry Weight }}{\text { Turgid Weight }- \text { Dry Weight }} \times 100
$$

The turgid weight was determined by maintaining the leaf in a humid environment $\left(4{ }^{\circ} \mathrm{C}\right.$ for $\left.24 \mathrm{~h}\right)$.

Electrolyte leakage was measured by following the method of Lutts et al. [72] with little modification. Leaf sample $\left(1 \mathrm{~cm}^{2}\right)$ were placed in test tubes with distilled water $(10 \mathrm{~mL})$, and electrical conductivity, $E C_{1}$, was measured with an $E C$ meter at room temperature. The tubes were placed on a mechanical shaker for $2 \mathrm{~h}$ in water and the $E C_{2}$ was calculated. The tubes were then autoclaved $\left(120^{\circ} \mathrm{C}\right)$ and $E C_{3}$ was determined upon cooling. Electrolyte leakage was measured by using the following formula:

$$
\text { Electrolyte Leakage }(\%)=\frac{E C_{2}-E C_{1}}{E C_{3}} \times 100
$$

\subsection{Measuring Maize Biochemical Attributes}

\subsubsection{Determination of Stress-Related Metabolites}

Stress-related metabolites, i.e., total soluble sugars concentrations, were analyzed by extracting the plant sample $(0.1 \mathrm{~g})$ in ethanol solution $(80 \%)$. The extracted material was taken in test tubes $(25 \mathrm{~mL})$ and added $6 \mathrm{~mL}$ anthrone reagent $(150 \mu \mathrm{g}$ of anthrone in $72 \%$ $\left.\mathrm{H}_{2} \mathrm{SO}_{4}\right)$ to each tube, heated in a boiling water bath $(10 \mathrm{~min})$, ice cooled, and incubated at room temperature $\left(25^{\circ} \mathrm{C}\right)$ for $20 \mathrm{~min}$. Spectrophotometer was used for measuring optical density at $625 \mathrm{~nm}$ and standard curve prepared from glucose was applied for the calculation of soluble sugars [73].

For proline content, the leaf sample $(1 \mathrm{~g})$ was homogenized in sulphosalicylic acid $(3 \%)$, and filtered and the mixture was heated in a test tube on addition of glacial acetic acid and acid ninhydrin in a water bath $\left(100{ }^{\circ} \mathrm{C}\right.$ for one hour). The tubes were ice cooled to stop the reaction, extracted with toluene, and spectrophotometer absorbance at $520 \mathrm{~nm}$ was recorded [74].

For lipid peroxidation, malondialdehyde (MDA) content was determined by homogenizing the plant fresh leaf $(200 \mathrm{~g})$ in trichloroacetic acid $(0.1 \%)$ and centrifuged $(10,000 \mathrm{rpm}$ for $15 \mathrm{~min})$. The supernatant $(1 \mathrm{~mL})$ was mixed with $20 \%$ trichloroacetic acid $(2 \mathrm{~mL})$ and $0.5 \%$ thiobarbituric acid $(2 \mathrm{~mL})$ in test tubes, heated in a water bath $\left(90^{\circ} \mathrm{C}\right.$ for half an hour) and ice cooled to stop the reaction. The concentration of MDA content in term of lipid peroxidation was determined by spectrophotometric absorbance at $532 \mathrm{~nm}$ [72].

\subsubsection{Antioxidant Enzymes Assay}

Frozen plant leaf was homogenized in an ice-cold mixture of potassium phosphate buffer $(0.2 \mathrm{M})$ and EDTA $(0.1 \mathrm{mM})$ solution.

Ascorbate peroxidase (APX) activity was measured by a decrease in the spectrophotometer absorbance at $290 \mathrm{~nm}$ due to oxidation of ascorbate in the reaction [75].

Glutathione peroxidase (GPX) activity was calculated by a reaction of a sodium azide, glutathione, and GPX solution into a $\mathrm{B}-\mathrm{NADPH}$ (nicotinamide adenine dinucleotide phosphate) flask, and the spectrophotometric absorbance at $340 \mathrm{~nm}$ was recorded [76].

Catalase (CAT) activity was observed by a decrease in the spectrophotometer absorbance at $240 \mathrm{~nm}$ due to loss of $\mathrm{H}_{2} \mathrm{O}_{2}$ [77].

Superoxide dismutase (SOD) activity was determined by monitoring the reaction mixture (sodium phosphate, EDTA, and pyrogallol) at $420 \mathrm{~nm}$ on a spectrophotometer [78]. 


\subsection{Chromium Speciation in Plant Tissues}

The double dry ashing method was used for digestion of plant root and shoot tissues for $\mathrm{Cr}$ determination [79]. $\mathrm{Cr}$ (VI) in plant tissues was analyzed by following the 1,5-diphenylcarbazide (DPC) method [67] with little modifications [68] using a spectrophotometer (Shimadzu UV-1800) at a $540 \mathrm{~nm}$ wavelength. For the total Cr concentration, an atomic absorption spectrophotometer (Perkin Elmer Aanalyst-100) was used and the $\mathrm{Cr}$ (III) concentration was determined by the difference method between $\mathrm{Cr}$ (VI) and total $\mathrm{Cr}$ concentration.

\subsection{Statistical Data Analysis}

All the collected data were analyzed by applying an ANOVA (analysis of variance) test to assess the variation among the mean values of different treatments applied on maize cultivars. Subsequently, Tukey's HSD (honestly significant difference) test was used to compare the treatment mean values at 5\% probability level [80] by using Statistix (version 8.1) (Analytical software, 2005, Florida, USA). Spearman's correlation analysis, using the program RStudio (R Software ${ }^{\circledR}$ version 4.0.2) (R Core Team, Boston, MA, USA), was applied to determine the correlation among all the studied parameters. Moreover, different experimental treatments with respect to all the studied morphological, physiological, and biochemical attributes of different maize cultivars in both $\mathrm{K}$ and $\mathrm{S}$ soils was also performed to compare the principal component analyses (PCA).

\section{Results}

\subsection{Impact of Biochar on Maize Growth}

In the present study, $\mathrm{Cr}$ toxicity adversely affected the plant growth of maize cultivars (NK-8441, P-1543, NK-8711, and FH-985) in tannery waste polluted soils, as shown in Table 3. In the control treatment (without biochar), $\mathrm{Cr}$ toxicity intensely reduced the plant height $(14.4 \mathrm{~cm})$, root length $(6.2 \mathrm{~cm})$, fresh weight of shoot $(2.9 \mathrm{~g})$, and root $(2.5 \mathrm{~g})$ along with shoot $(0.52 \mathrm{~g})$ and root $(0.34 \mathrm{~g})$ dry weight, as well as leaf area $\left(20 \mathrm{~cm}^{2}\right)$ of maize cultivar FH-985 in S soil. Conversely, biochar (3\%) application significantly improved the growth of all the studied maize cultivars in both $\mathrm{K}$ and $\mathrm{S}$ soils polluted with tannery waste. Here, the highest increase in the plant height (20.2\%), root length $(21.9 \%)$, and fresh weight of shoot $(19.8 \%)$ and root $(24.5 \%)$ along with the dry weight of shoot $(28.7 \%)$ and root $(20.2 \%)$, as well as the leaf area $(28.7 \%)$, was observed in the P-1543 cultivar of maize vegetated in $\mathrm{K}$ soil.

\subsection{Physiological Traits of Maize Plant}

The chromium toxicity influenced photosynthetic pigments and gaseous exchange measurement of all the maize cultivars differently in both $\mathrm{K}$ and $\mathrm{S}$ soils as presented in Table 4. In the control treatment, the harmful effects of $\mathrm{Cr}$ critically altered the SPAD chlorophyll content $\left(8.5 \mathrm{mg} \mathrm{cm}^{-2}\right)$, chlorophyll "a" $\left(0.14 \mathrm{mg} \mathrm{g}^{-1}\right)$ and "b" $\left(0.12 \mathrm{mg} \mathrm{g}^{-1}\right)$, A rate $\left(5.5 \mu \mathrm{mol} \mathrm{m} \mathrm{m}^{-2} \mathrm{~s}^{-1}\right), \mathrm{E}$ rate $\left(0.93 \mathrm{mmol} \mathrm{m}^{-2} \mathrm{~s}^{-1}\right), \mathrm{gs}\left(44 \mathrm{mmol} \mathrm{m}^{-2} \mathrm{~s}^{-1}\right)$, and total carotenoids content $\left(0.18 \mathrm{mg} \mathrm{g}^{-1}\right)$ of maize cultivar FH-985 in S soil. Biochar (3\%) application significantly improved the physiological traits in both soils and most distantly increased the SPAD chlorophyll content $(21.5 \%)$, chlorophyll "a" (21.4\%), chlorophyll " $\mathrm{b}$ " $(19.8 \%)$, total carotenoids content $(18.8 \%)$, A rate $(20.3 \%)$, E rate $(24.8 \%)$, and gs $(19.2 \%)$ of maize cultivar P-1543 in K soil. 
Table 3. Plant growth parameters of studied maize cultivars NK-8441, P-1543, NK-8711, and FH-985 with the application of biochar in tannery polluted Kasur and Sialkot soils.

\begin{tabular}{|c|c|c|c|c|c|c|c|c|c|}
\hline \multirow{2}{*}{ Soil } & \multirow{2}{*}{ Biochar } & \multirow{2}{*}{ Maize Variety } & \multicolumn{2}{|c|}{ Plant Height (cm) } & \multicolumn{2}{|c|}{ Fresh Weight (g) } & \multicolumn{2}{|c|}{ Dry Weight (g) } & \multirow{2}{*}{ Leaf Area $\left(\mathrm{cm}^{2}\right.$} \\
\hline & & & Shoot & Root & Shoot & Root & Shoot & Root & \\
\hline \multirow{7}{*}{$\begin{array}{c}\mathrm{K} \\
\text { soil }\end{array}$} & \multirow{4}{*}{$0 \%$} & NK-8441 & $43.1 \pm 1.09 \mathrm{de}$ & $27.3 \pm 0.79 \mathrm{de}$ & $17.7 \pm 0.51 \mathrm{~d}$ & $9.4 \pm 0.27 \mathrm{de}$ & $1.83 \pm 0.05 \mathrm{de}$ & $1.37 \pm 0.03 \mathrm{de}$ & $81 \pm 1.94 \mathrm{e}$ \\
\hline & & P-1543 & $48.1 \pm 0.93 \mathrm{bc}$ & $31.6 \pm 0.59 \mathrm{bc}$ & $20.1 \pm 0.54 \mathrm{bc}$ & $10.9 \pm 0.30 \mathrm{bc}$ & $2.13 \pm 0.07 c$ & $1.62 \pm 0.04 \mathrm{bc}$ & $93 \pm 2.73 \mathrm{~cd}$ \\
\hline & & NK-8711 & $38.1 \pm 0.48 \mathrm{fg}$ & $23.3 \pm 0.69 \mathrm{fg}$ & $15.2 \pm 0.41 \mathrm{e}$ & $8.0 \pm 0.23 \mathrm{f}-\mathrm{h}$ & $1.52 \pm 0.06 \mathrm{fg}$ & $1.13 \pm 0.04 \mathrm{fg}$ & $69 \pm 2.33 \mathrm{fg}$ \\
\hline & & FH-985 & $33.1 \pm 0.96 \mathrm{hi}$ & $19.0 \pm 0.59 \mathrm{hi}$ & $12.5 \pm 0.45 \mathrm{fg}$ & $6.3 \pm 0.21 \mathrm{ij}$ & $1.20 \pm 0.04 \mathrm{~h}-\mathrm{j}$ & $0.90 \pm 0.04 \mathrm{~h}-\mathrm{j}$ & $57 \pm 1.51 \mathrm{hi}$ \\
\hline & \multirow{3}{*}{$3 \%$} & NK-8441 & $51.9 \pm 0.74 b$ & $34.0 \pm 0.86 \mathrm{~b}$ & $21.0 \pm 0.45 b$ & $12.0 \pm 0.25 b$ & $2.42 \pm 0.05 \mathrm{~b}$ & $1.72 \pm 0.05 \mathrm{~b}$ & $106 \pm 2.00 \mathrm{~b}$ \\
\hline & & P-1543 & $57.9 \pm 1.16 \mathrm{a}$ & $38.5 \pm 0.49 a$ & $24.1 \pm 0.65 \mathrm{a}$ & $13.6 \pm 0.36 \mathrm{a}$ & $2.75 \pm 0.07 \mathrm{a}$ & $1.94 \pm 0.06 \mathrm{a}$ & $118 \pm 3.13 \mathrm{a}$ \\
\hline & & FH-985 & $41.6 \pm 1.15$ ef & $26.3 \pm 0.60$ ef & $15.0 \pm 0.43 \mathrm{e}$ & $9.0 \pm 0.27$ e-g & $1.78 \pm 0.04$ ef & $1.24 \pm 0.04 \mathrm{e}-\mathrm{g}$ & $82 \pm 2.21 \mathrm{de}$ \\
\hline \multirow{7}{*}{$\begin{array}{c}\text { S } \\
\text { soil }\end{array}$} & \multirow{4}{*}{$0 \%$} & NK-8441 & $24.7 \pm 0.73 \mathrm{kl}$ & $13.7 \pm 0.71 \mathrm{jk}$ & $7.7 \pm 0.34 \mathrm{ij}$ & $5.4 \pm 0.22 \mathrm{jk}$ & $1.09 \pm 0.04 \mathrm{jk}$ & $0.81 \pm 0.05 \mathrm{jk}$ & $44 \pm 2.06 \mathrm{jk}$ \\
\hline & & P-1543 & $29.9 \pm 0.73 \mathrm{ij}$ & $17.9 \pm 0.79 \mathrm{hi}$ & $10.1 \pm 0.43 \mathrm{gh}$ & $6.9 \pm 0.26 \mathrm{hi}$ & $1.40 \pm 0.06 \mathrm{~g}-\mathrm{i}$ & $1.05 \pm 0.03 \mathrm{gi}$ & $56 \pm 2.08 \mathrm{hi}$ \\
\hline & & NK-8711 & $19.6 \pm 1.20 \mathrm{~m}$ & $9.9 \pm 0.391$ & $5.3 \pm 0.35 \mathrm{k}$ & $3.9 \pm 0.211$ & $0.81 \pm 0.051$ & $0.58 \pm 0.031$ & $32 \pm 1.811$ \\
\hline & & FH-985 & $14.4 \pm 0.97 \mathrm{n}$ & $6.2 \pm 0.52 \mathrm{~m}$ & $2.9 \pm 0.211$ & $2.5 \pm 0.20 \mathrm{~m}$ & $0.52 \pm 0.03 \mathrm{~m}$ & $0.34 \pm 0.04 \mathrm{~m}$ & $20 \pm 1.79 \mathrm{~m}$ \\
\hline & \multirow{3}{*}{$3 \%$} & NK-8441 & $30.8 \pm 0.97 \mathrm{hi}$ & $20.3 \pm 0.82 \mathrm{gh}$ & $11.6 \pm 0.50 \mathrm{~g}$ & $7.8 \pm 0.27 \mathrm{gh}$ & $1.46 \pm 0.05 \mathrm{gh}$ & $1.10 \pm 0.03 \mathrm{gh}$ & $63 \pm 2.63 \mathrm{gh}$ \\
\hline & & P-1543 & $35.5 \pm 0.94 \mathrm{gh}$ & $24.5 \pm 0.52$ ef & $14.5 \pm 0.53 \mathrm{ef}$ & $9.2 \pm 0.31 \mathrm{~d}-\mathrm{f}$ & $1.78 \pm 0.07 \mathrm{ef}$ & $1.35 \pm 0.05 \mathrm{~d}-\mathrm{f}$ & $75 \pm 2.04$ ef \\
\hline & & NK-8711 & $25.7 \pm 0.70 \mathrm{jk}$ & $16.2 \pm 0.60 \mathrm{ij}$ & $8.8 \pm 0.23 \mathrm{hi}$ & $6.3 \pm 0.21 \mathrm{ij}$ & $1.13 \pm 0.05 \mathrm{ij}$ & $0.87 \pm 0.04 \mathrm{ij}$ & $51 \pm 1.68 \mathrm{ij}$ \\
\hline
\end{tabular}

The values are mean \pm S.E. $(\mathrm{n}=3)$. Mean values with different alphabetical letters are significantly different $(p<0.05)$ according to Tukey's HSD test; K: Kasur soil; S: Sialkot soil. 
Table 4. Plant physiological parameters of maize cultivars NK-8441, P-1543, NK-8711, and FH-985 with the application of biochar in tannery polluted Kasur and Sialkot soils.

\begin{tabular}{|c|c|c|c|c|c|c|c|c|c|}
\hline \multirow{2}{*}{ Soil } & \multirow{2}{*}{ Biochar } & \multirow{2}{*}{ Maize Variety } & $\begin{array}{c}\text { SPAD } \\
\text { Chlorophyll }\end{array}$ & $\begin{array}{c}\text { Chlorophyll } \\
\text { a }\end{array}$ & $\begin{array}{c}\text { Chlorophyll } \\
\text { b }\end{array}$ & $\begin{array}{c}\text { Total } \\
\text { Carotenoids }\end{array}$ & $\begin{array}{c}\text { Photosynthetic } \\
\text { Rate }\end{array}$ & $\begin{array}{c}\text { Transpiration } \\
\text { Rate }\end{array}$ & $\begin{array}{c}\text { Stomatal } \\
\text { Conductance }\end{array}$ \\
\hline & & & $\left(\mathrm{mg} \mathrm{cm}^{-2}\right)$ & $\left(\mathrm{mg} \mathrm{g}^{-1}\right)$ & $\left(\mathrm{mg} \mathrm{g}^{-1}\right)$ & $\left(\mathrm{mg} \mathrm{g}^{-1}\right)$ & $\left(\mu \mathrm{mol} \mathrm{m} \mathrm{m}^{-2} \mathrm{~s}^{-1}\right)$ & $\left(\mathrm{mmol} \mathrm{m} \mathrm{m}^{-2} \mathrm{~s}^{-1}\right)$ & $\left(\mathrm{mmol} \mathrm{m} \mathrm{m}^{-2} \mathrm{~s}^{-1}\right)$ \\
\hline \multirow{7}{*}{$\begin{array}{c}\mathrm{K} \\
\text { soil }\end{array}$} & \multirow{4}{*}{$0 \%$} & NK-8441 & $30.1 \pm 0.61 \mathrm{de}$ & $0.54 \pm 0.02 \mathrm{~d}-\mathrm{f}$ & $0.44 \pm 0.01 \mathrm{~d}-\mathrm{f}$ & $0.65 \pm 0.02 \mathrm{~cd}$ & $17.2 \pm 0.41 \mathrm{de}$ & $2.90 \pm 0.06 \mathrm{~d}$ & $149 \pm 3.15 \mathrm{de}$ \\
\hline & & P-1543 & $34.0 \pm 0.83 \mathrm{bc}$ & $0.63 \pm 0.02 \mathrm{bc}$ & $0.52 \pm 0.01 \mathrm{bc}$ & $0.77 \pm 0.02 \mathrm{~b}$ & $19.8 \pm 0.55 b c$ & $3.37 \pm 0.09 c$ & $178 \pm 4.99 \mathrm{bc}$ \\
\hline & & NK-8711 & $26.0 \pm 0.67 \mathrm{fg}$ & $0.44 \pm 0.02 \mathrm{gh}$ & $0.36 \pm 0.01 \mathrm{~g}$ & $0.54 \pm 0.02 \mathrm{e}$ & $14.5 \pm 0.47 \mathrm{f}$ & $2.40 \pm 0.06 \mathrm{e}$ & $125 \pm 4.67 \mathrm{fg}$ \\
\hline & & FH-985 & $21.7 \pm 0.56 \mathrm{hi}$ & $0.35 \pm 0.02 \mathrm{i}-\mathrm{k}$ & $0.29 \pm 0.01 \mathrm{hi}$ & $0.43 \pm 0.02 \mathrm{fg}$ & $11.9 \pm 0.36 \mathrm{gh}$ & $2.00 \pm 0.06 \mathrm{f}$ & $102 \pm 3.07 \mathrm{~h}-\mathrm{j}$ \\
\hline & \multirow{3}{*}{$3 \%$} & NK-8441 & $37.0 \pm 0.79 \mathrm{~b}$ & $0.66 \pm 0.02 \mathrm{~b}$ & $0.54 \pm 0.02 \mathrm{~b}$ & $0.78 \pm 0.02 \mathrm{~b}$ & $21.1 \pm 0.41 \mathrm{~b}$ & $3.73 \pm 0.09 \mathrm{~b}$ & $183 \pm 3.72 \mathrm{~b}$ \\
\hline & & NK-8711 & $33.0 \pm 0.84 \mathrm{~cd}$ & $0.57 \pm 0.02 \mathrm{~cd}$ & $0.46 \pm 0.01 \mathrm{~cd}$ & $0.67 \pm 0.02 c$ & $18.2 \pm 0.55 \mathrm{~cd}$ & $3.23 \pm 0.07 c$ & $163 \pm 4.42 \mathrm{~cd}$ \\
\hline & & FH-985 & $28.5 \pm 0.72$ ef & $0.47 \pm 0.02 \mathrm{e}-\mathrm{g}$ & $0.39 \pm 0.01 \mathrm{e}-\mathrm{g}$ & $0.56 \pm 0.02 \mathrm{de}$ & $15.4 \pm 0.38$ ef & $2.63 \pm 0.09 \mathrm{de}$ & $141 \pm 3.78$ ef \\
\hline \multirow{6}{*}{$\begin{array}{c}\text { S } \\
\text { soil }\end{array}$} & \multirow{4}{*}{$0 \%$} & NK-8441 & $17.7 \pm 0.61 \mathrm{jk}$ & $0.33 \pm 0.02 \mathrm{Jk}$ & $0.27 \pm 0.01 \mathrm{ij}$ & $0.38 \pm 0.02 \mathrm{gh}$ & $10.4 \pm 0.30 \mathrm{hi}$ & $1.83 \pm 0.07 \mathrm{f}$ & $86 \pm 3.69 \mathrm{jk}$ \\
\hline & & P-1543 & $22.0 \pm 0.83 \mathrm{hi}$ & $0.43 \pm 0.02 \mathrm{~g}-\mathrm{i}$ & $0.35 \pm 0.02 \mathrm{gh}$ & $0.50 \pm 0.02 \mathrm{ef}$ & $13.2 \pm 0.32 \mathrm{fg}$ & $2.40 \pm 0.06 \mathrm{e}$ & $108 \pm 3.85 \mathrm{~g}-\mathrm{i}$ \\
\hline & & NK-8711 & $13.8 \pm 0.591$ & $0.23 \pm 0.011$ & $0.19 \pm 0.01 \mathrm{k}$ & $0.27 \pm 0.02 \mathrm{i}$ & $8.0 \pm 0.43 j$ & $1.37 \pm 0.07 \mathrm{~g}$ & $66 \pm 3.09 \mathrm{k}$ \\
\hline & & FH-985 & $8.5 \pm 0.42 \mathrm{~m}$ & $0.14 \pm 0.01 \mathrm{~m}$ & $0.12 \pm 0.011$ & $0.18 \pm 0.01 \mathrm{j}$ & $5.5 \pm 0.42 \mathrm{k}$ & $0.93 \pm 0.07 \mathrm{~h}$ & $44 \pm 2.091$ \\
\hline & \multirow{2}{*}{$3 \%$} & NK-8441 & $24.8 \pm 0.66 \mathrm{gh}$ & $0.46 \pm 0.02 \mathrm{fg}$ & $0.37 \pm 0.01 \mathrm{fg}$ & $0.54 \pm 0.02 \mathrm{e}$ & $14.4 \pm 0.25 \mathrm{f}$ & $2.43 \pm 0.09 \mathrm{e}$ & $120 \pm 2.89 \mathrm{gh}$ \\
\hline & & P-1543 & $28.7 \pm 0.82 \mathrm{ef}$ & $0.56 \pm 0.02 \mathrm{c}-\mathrm{e}$ & $0.45 \pm 0.02 \mathrm{de}$ & $0.65 \pm 0.02 \mathrm{~cd}$ & $17.1 \pm 0.69 \mathrm{de}$ & $2.87 \pm 0.07 \mathrm{~d}$ & $143 \pm 5.01 \mathrm{~d}-\mathrm{f}$ \\
\hline
\end{tabular}

The values are mean \pm S.E. $(n=3)$. Mean values with different alphabetical letters are significantly different $(p<0.05)$ according to Tukey's HSD test; K: Kasur soil; S: Sialkot soil. 
Data showed that the RWC (Figure 1) and EL of all the maize cultivars (NK-8441, P-1543, NK-8711, and FH-985) were also affected by the damaging and toxic effects caused by $\mathrm{Cr}$ (Figure 2). A decrease in the RWC and an increase in the level of EL of maize plants were noticed in both soils. In the control treatment, an acute decrease in RWC $(12 \%)$ and increase in EL (12.1\%) of maize cultivar FH-985 was observed in S soil, while treatment involving biochar (3\%) application provided relief to all maize cultivars and improved the RWC and EL in both soils. The sharp gain in RWC (23.5\%) and decrease of EL (47\%) in maize cultivar P-1543 was observed in K soil only.

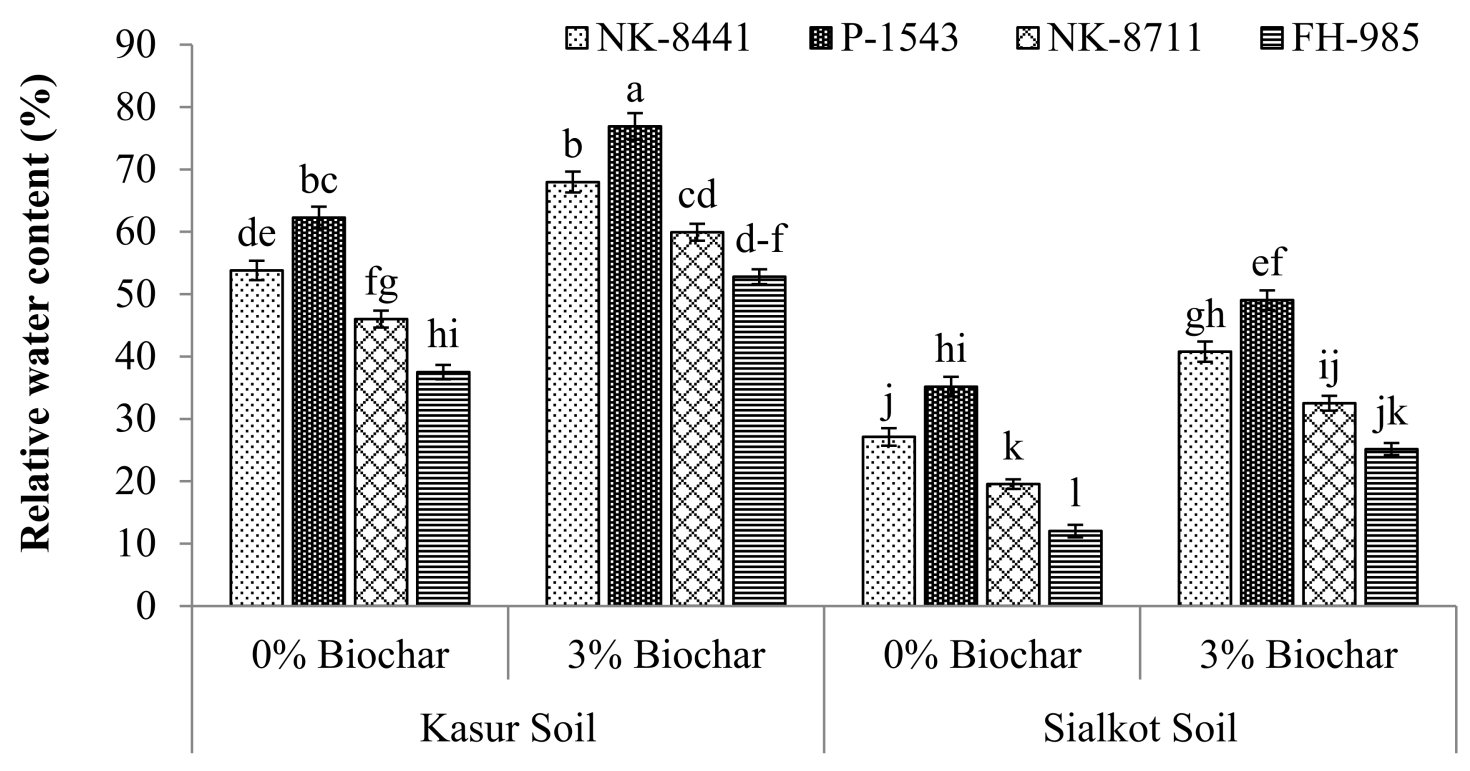

Figure 1. Relative water content of studied maize cultivars with the application of biochar in the tannery polluted soils of Kasur and Sialkot. Mean values are indicated by the columns and the standard error of the mean is shown with bars. All means followed by different letters are significantly different $(p<0.05)$ according to Tukey's HSD test.

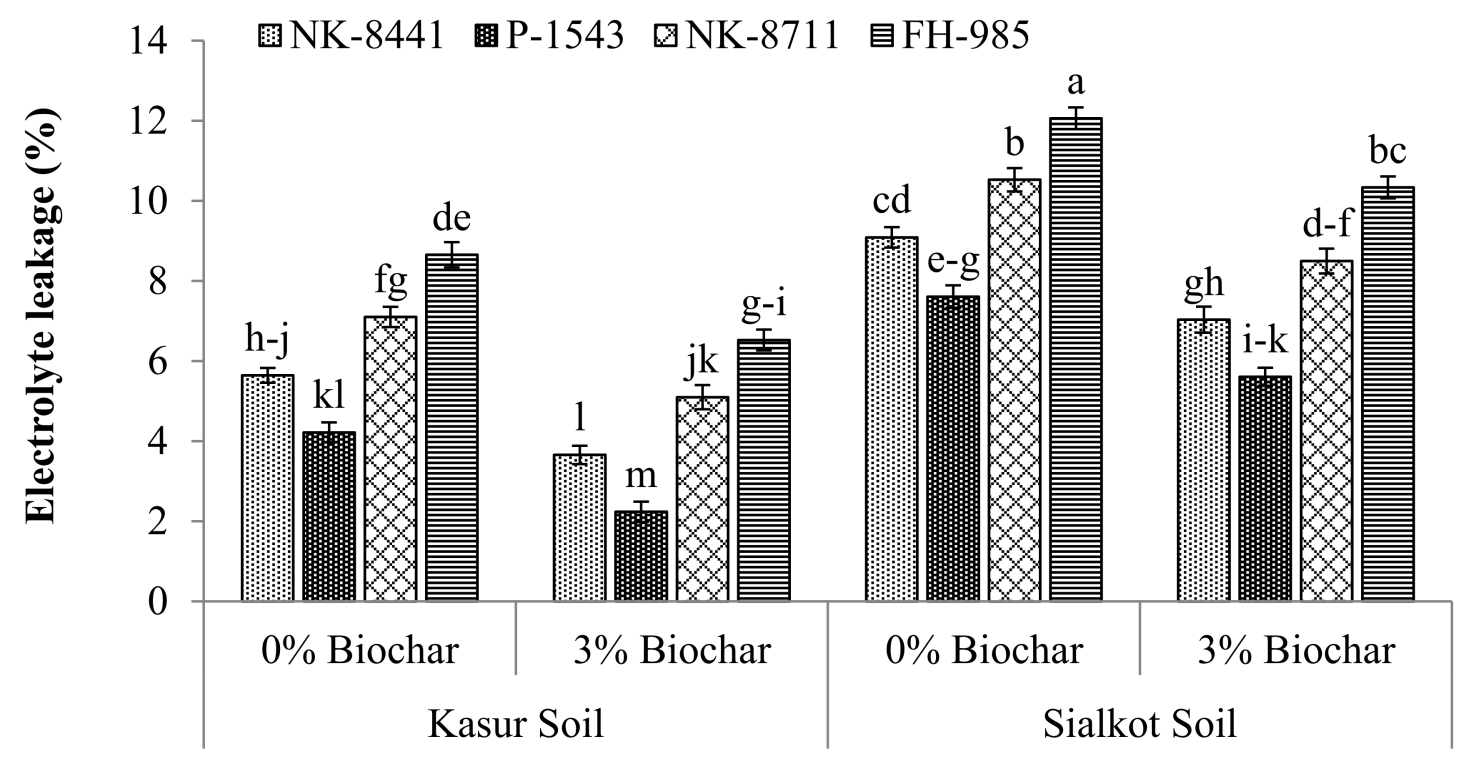

Figure 2. Electrolyte leakage of studied maize cultivars with the application of biochar in the tannery polluted soils of Kasur and Sialkot. Mean values are indicated by columns and the standard error of the mean is shown with bars. All means followed by different letters are significantly different $(p<0.05)$ according to Tukey's HSD test. 


\subsection{Biochemical Attributes of the Plants}

\subsubsection{Stress-Related Metabolites}

Rise in stress related metabolites of all the studied maize cultivars (NK-8441, P-1543, NK-8711, and FH-985) was observed in both soils (K and S) as shown in (Table 5). In control treatment, toxic $\mathrm{Cr}$ (VI) extremely increased the soluble sugars $\left(83.7 \mathrm{mg} \mathrm{g}^{-1}\right)$, lipid peroxidation, and proline content $\left(8.36 \mu \mathrm{g} \mathrm{g}^{-1}\right)$ in the form of malondialdehyde (146 $\mathrm{mmol} \mathrm{g}^{-1}$ ) of maize cultivar FH-985 in S soil. A significant reduction in the metabolites activity was found on the application of biochar (3\%) in both soils. Biochar strongly decreased the soluble sugars, lipid peroxidation, and proline content in maize cultivar P-1543 up to $43.9 \%, 48.4 \%$, and 38\%, respectively, in K soil.

\subsubsection{Measurement of Antioxidant Enzyme Activities}

Chromium-induced toxicity in tannery polluted soils also transformed the antioxidant enzyme activities of maize plant (Table 5). An increase in enzymes (APX, GPX, CAT, and SOD) activity of all the studied maize cultivars was found in both soils. Chromium predominantly increased the APX $\left(76.8 \mathrm{nmol} \mathrm{min}{ }^{-1} \mathrm{mg}^{-1}\right)$, GPX $\left(98.3 \mathrm{nmol} \mathrm{min}{ }^{-1} \mathrm{mg}^{-1}\right)$, CAT (27.8 nmol min $\left.{ }^{-1} \mathrm{mg}^{-1}\right)$, and SOD $\left(289 \mathrm{nmol} \mathrm{min}^{-1} \mathrm{mg}^{-1}\right.$ ) of maize cultivar FH985 in the control treatment of $S$ soil. Biochar (3\%) application significantly reduced the antioxidant enzymes activity and principally decreased the activity of APX (50.6\%), GPX (58.4\%), CAT (52.5\%), and SOD (50.3\%) of P-1543 maize cultivar in K soil.

\subsection{Chromium Concentration in Soil and Plant Tissues}

The accumulation of Cr greatly varied in the soil as well as in the root and shoot of all the studied maize cultivars (Table 6). Cultivar FH-985 in both soils accumulated $\mathrm{Cr}$ (III and VI) mostly in the plant root and shoot tissues and less amounts in the soil. The lowest amount of $\mathrm{Cr}$ (III) and $\mathrm{Cr}$ (VI) was $18.2 \mu \mathrm{g} \mathrm{g}^{-1}$ and $4.3 \mu \mathrm{g} \mathrm{g}^{-1}$, respectively, in $\mathrm{K}$ soil. The highest accumulation of $\mathrm{Cr}$ (III) was $307 \mu \mathrm{g} \mathrm{g}^{-1}$ in root and $251 \mu \mathrm{g} \mathrm{g}^{-1}$ in shoot, while $\mathrm{Cr}$ (VI) was $142 \mu \mathrm{g} \mathrm{g}^{-1}$ in root and $110 \mu \mathrm{g} \mathrm{g}^{-1}$ in shoot of $\mathrm{S}$ soil. In contrast to cultivar FH-985, cultivar P-1543 mostly accumulated dominant species of Cr (III and VI) in soil, while it decreased its accumulation in maize roots and shoots. The application of biochar $(3 \%)$ resolved this issue, by significantly lowering the $\mathrm{Cr}$ (VI) concentration (available fraction) and increasing the $\mathrm{Cr}$ (III) concentration (less soluble fraction) in soil along with a reduction in $\mathrm{Cr}$ (III and VI) accumulation in root and shoot. Moreover, applied biochar increased $\mathrm{Cr}$ (III) accumulation up to $67.4 \mu \mathrm{g} \mathrm{g}{ }^{-1}$ in cultivar P-1543 of S soil and decreased the accumulation of $\mathrm{Cr}$ (III) (53 and $\left.41 \mu \mathrm{g} \mathrm{g}^{-1}\right)$ and $\mathrm{Cr}$ (VI) $\left(27\right.$ and $\left.21 \mu \mathrm{g} \mathrm{g}^{-1}\right)$ in root and shoot of K soil, respectively.

\subsection{Correlation and Principal Component Analyses}

Significant positive and negative relationships were observed among all the studied morphological and physiological attributes of the maize plant and $\mathrm{Cr}$ concentrations in soil and plant tissues (Figure 3). In the same way, a tremendously positive relationship was also observed among all the measured antioxidant enzymes. Principal component analysis was applied to assess the distribution of different treatments carried out on maize cultivars (NK8441, P-1543, NK-8711, and FH-985) in tested soils as presented by a biplot (Figure 4). From the biplot of PCA, remarkable outcomes were obtained presenting excessive variability among all the studied parameters measured in different maize cultivars, with the first two major constituents interpreting a variability of $95.8 \%$. C Cultivar FH-985 in maize vegetated in $\mathrm{S}$ soil showed the maximum coordinate on the biplot of the PCA, indicating that it is the most effective treatment, followed by cultivar NK-8711 in the same soil type. The PCA biplot also revealed that the concentration of Cr species (III and VI)) is highly positively correlated to each other in root and shoot of the plants and antioxidant enzymes, whereas all the morpho and physiological attributes of the maize plants are highly negatively correlated while they are highly positively correlated among themselves. 


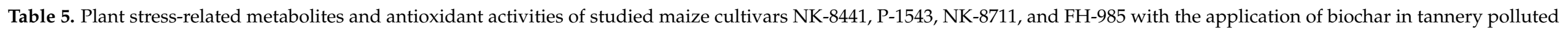
Kasur and Sialkot soils.

\begin{tabular}{|c|c|c|c|c|c|c|c|c|c|}
\hline \multirow{2}{*}{ Soil } & \multirow{2}{*}{ Biochar } & \multirow{2}{*}{ Maize Variety } & Soluble Sugars & Proline Content & $\begin{array}{c}\text { Lipid } \\
\text { Peroxidation }\end{array}$ & $\begin{array}{l}\text { Ascorbate } \\
\text { Peroxidase }\end{array}$ & $\begin{array}{l}\text { Glutathione } \\
\text { Peroxidase }\end{array}$ & Catalase & $\begin{array}{l}\text { Superoxide } \\
\text { Dismutase }\end{array}$ \\
\hline & & & $\left(\mathrm{mg} \mathrm{g}^{-1}\right)$ & $\left(\mu \mathrm{mol} \mathrm{g}{ }^{-1}\right)$ & $\left(\mathrm{mmol} \mathrm{g}^{-1}\right)$ & $\begin{array}{c}\left(\mathrm{nmol} \mathrm{min}^{-1}\right. \\
\left.\mathrm{mg}^{-1}\right)\end{array}$ & $\begin{array}{c}\left(\mathrm{nmol} \mathrm{min}^{-1}\right. \\
\left.\mathrm{mg}^{-1}\right)\end{array}$ & $\begin{array}{c}(\mathrm{nmol} \mathrm{min} \\
\left.\mathrm{mg}^{-1}\right)\end{array}$ & $\begin{array}{c}(\mathrm{nmol} \mathrm{min} \\
\left.\mathrm{mg}^{-1}\right)\end{array}$ \\
\hline \multirow{7}{*}{$\begin{array}{c}\mathrm{K} \\
\text { soil }\end{array}$} & \multirow{4}{*}{$0 \%$} & NK-8441 & $37.6 \pm 1.62 \mathrm{jk}$ & $3.65 \pm 0.16 \mathrm{ij}$ & $69 \pm 2.77 \mathrm{hi}$ & $34.7 \pm 1.30 \mathrm{jk}$ & $46.1 \pm 2.00 \mathrm{ij}$ & $13.5 \pm 0.45 \mathrm{hi}$ & $132 \pm 4.43 \mathrm{gh}$ \\
\hline & & P-1543 & $28.8 \pm 1.57 \mathrm{~lm}$ & $2.81 \pm 0.14 \mathrm{kl}$ & $54 \pm 1.93 \mathrm{jk}$ & $26.0 \pm 1.151$ & $34.9 \pm 1.83 \mathrm{kl}$ & $10.3 \pm 0.40 \mathrm{jk}$ & $94 \pm 4.57 \mathrm{ij}$ \\
\hline & & NK-8711 & $46.2 \pm 1.02 \mathrm{~g}-\mathrm{i}$ & $4.71 \pm 0.14 \mathrm{gh}$ & $85 \pm 2.77 \mathrm{fg}$ & $43.1 \pm 1.53 \mathrm{~g}-\mathrm{i}$ & $57.4 \pm 2.29 \mathrm{f}-\mathrm{h}$ & $16.8 \pm 0.57 \mathrm{fg}$ & $164 \pm 5.18$ ef \\
\hline & & FH-985 & $56.6 \pm 1.67 \mathrm{~d}-\mathrm{f}$ & $5.87 \pm 0.15 \mathrm{de}$ & $104 \pm 3.07 \mathrm{c}-\mathrm{e}$ & $52.4 \pm 1.69 \mathrm{~d}-\mathrm{f}$ & $69.1 \pm 2.48 \mathrm{c}-\mathrm{e}$ & $20.3 \pm 0.62 \mathrm{de}$ & $203 \pm 5.48 \mathrm{~cd}$ \\
\hline & \multirow{3}{*}{$3 \%$} & P-1543 & $16.2 \pm 1.23 \mathrm{n}$ & $1.74 \pm 0.11 \mathrm{~m}$ & $28 \pm 1.541$ & $12.8 \pm 1.17 \mathrm{~m}$ & $14.5 \pm 1.52 \mathrm{~m}$ & $4.9 \pm 0.341$ & $47 \pm 3.85 \mathrm{k}$ \\
\hline & & NK-8711 & $32.9 \pm 1.62 \mathrm{kl}$ & $3.37 \pm 0.15 \mathrm{jk}$ & $57 \pm 2.77 \mathrm{ij}$ & $28.7 \pm 1.30 \mathrm{kl}$ & $37.4 \pm 1.92 \mathrm{jk}$ & $11.1 \pm 0.51 \mathrm{ij}$ & $114 \pm 5.03 \mathrm{hi}$ \\
\hline & & FH-985 & $42.7 \pm 1.27 \mathrm{~h}-\mathrm{j}$ & $4.19 \pm 0.17 \mathrm{hi}$ & $74 \pm 2.35 \mathrm{gh}$ & $37.2 \pm 1.45 \mathrm{~h}-\mathrm{j}$ & $49.7 \pm 2.10 \mathrm{~g}-\mathrm{i}$ & $14.6 \pm 0.54 \mathrm{gh}$ & $147 \pm 5.76 \mathrm{fg}$ \\
\hline \multirow{6}{*}{$\begin{array}{c}\text { S } \\
\text { soil }\end{array}$} & \multirow{4}{*}{$0 \%$} & NK-8441 & $61.6 \pm 1.27 \mathrm{~cd}$ & $6.47 \pm 0.12 \mathrm{~cd}$ & $114 \pm 1.73 \mathrm{c}$ & $57.8 \pm 1.59 \mathrm{~cd}$ & $74.7 \pm 1.91 \mathrm{c}$ & $21.6 \pm 0.55 \mathrm{~cd}$ & $215 \pm 5.63 c$ \\
\hline & & P-1543 & $51.6 \pm 2.08 \mathrm{e}-\mathrm{g}$ & $5.56 \pm 0.14$ ef & $98 \pm 3.00 \mathrm{~d}-\mathrm{f}$ & $48.3 \pm 1.45 \mathrm{e}-\mathrm{g}$ & $63.6 \pm 1.92 \mathrm{~d}-\mathrm{f}$ & $18.4 \pm 0.55 \mathrm{ef}$ & $179 \pm 5.52 \mathrm{de}$ \\
\hline & & NK-8711 & $71.3 \pm 1.30 \mathrm{~b}$ & $7.46 \pm 0.17 b$ & $130 \pm 2.88 \mathrm{~b}$ & $67.3 \pm 1.74 \mathrm{~b}$ & $86.9 \pm 2.10 b$ & $24.8 \pm 0.58 \mathrm{~b}$ & $252 \pm 6.04 b$ \\
\hline & & FH-985 & $83.7 \pm 1.91 \mathrm{a}$ & $8.36 \pm 0.19 \mathrm{a}$ & $146 \pm 3.20 \mathrm{a}$ & $76.8 \pm 2.03 \mathrm{a}$ & $98.3 \pm 2.50 \mathrm{a}$ & $27.8 \pm 0.71 \mathrm{a}$ & $289 \pm 6.70 \mathrm{a}$ \\
\hline & \multirow{2}{*}{$3 \%$} & NK-8441 & $48.7 \pm 1.69 \mathrm{f}-\mathrm{h}$ & $5.07 \pm 0.13 \mathrm{fg}$ & $91 \pm 2.18$ ef & $44.8 \pm 1.38 \mathrm{f}-\mathrm{h}$ & $59.3 \pm 2.19 \mathrm{e}-\mathrm{g}$ & $17.2 \pm 0.49 \mathrm{fg}$ & $168 \pm 5.23 \mathrm{ef}$ \\
\hline & & FH-985 & $69.1 \pm 1.64 b c$ & $6.97 \pm 0.15 b c$ & $129 \pm 2.61 b$ & $65.8 \pm 1.81 \mathrm{bc}$ & $86.6 \pm 2.41 b$ & $24.4 \pm 0.60 \mathrm{bc}$ & $252 \pm 5.52 b$ \\
\hline
\end{tabular}

The values are mean \pm S.E. $(n=3)$. Mean values with different alphabetical letters are significantly different $(p<0.05)$ according to Tukey's HSD test; K: Kasur soil; S: Sialkot soil. 


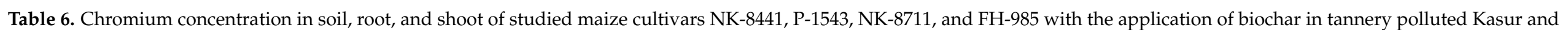
Sialkot soils.

\begin{tabular}{|c|c|c|c|c|c|c|c|c|}
\hline \multirow{2}{*}{ Soil } & \multirow{2}{*}{ Biochar } & \multirow{2}{*}{ Maize Variety } & \multicolumn{2}{|c|}{ Soil $\left(\mu g g^{-1}\right)$} & \multicolumn{2}{|c|}{$\operatorname{Root}\left(\mu \mathrm{g} \mathrm{g}^{-1}\right)$} & \multicolumn{2}{|c|}{ Shoot $\left(\mu g^{-1}\right)$} \\
\hline & & & Cr (III) & $\mathrm{Cr}(\mathrm{VI})$ & Cr (III) & $\mathrm{Cr}(\mathrm{VI})$ & Cr (III) & $\mathrm{Cr}(\mathrm{VI})$ \\
\hline \multirow{8}{*}{$\begin{array}{c}\mathrm{K} \\
\text { soil }\end{array}$} & \multirow{4}{*}{$0 \%$} & NK-8441 & $28.4 \pm 0.83 \mathrm{~m}$ & $12.2 \pm 0.40 \mathrm{fg}$ & $132 \pm 5.00 \mathrm{i}$ & $65 \pm 2.78 \mathrm{hi}$ & $105 \pm 4.00 \mathrm{ij}$ & $50 \pm 2.15 \mathrm{jk}$ \\
\hline & & P-1543 & $33.5 \pm 0.93 \mathrm{kl}$ & $14.3 \pm 0.42 \mathrm{c}-\mathrm{e}$ & $102 \pm 5.07 \mathrm{kl}$ & $50 \pm 1.56 \mathrm{jk}$ & $79 \pm 3.40 \mathrm{kl}$ & $38 \pm 2.08 \mathrm{~lm}$ \\
\hline & & NK-8711 & $23.2 \pm 0.81 \mathrm{n}$ & $10.0 \pm 0.38 \mathrm{~h}-\mathrm{j}$ & $168 \pm 5.38 \mathrm{gh}$ & $80 \pm 3.46 \mathrm{fg}$ & $130 \pm 5.13 \mathrm{gh}$ & $61 \pm 1.34 \mathrm{~g}-\mathrm{i}$ \\
\hline & & FH-985 & $18.2 \pm 0.77 \mathrm{o}$ & $7.9 \pm 0.35 \mathrm{kl}$ & $197 \pm 6.83$ ef & $99 \pm 2.60 \mathrm{de}$ & $161 \pm 4.78 \mathrm{~d}-\mathrm{f}$ & $74 \pm 2.23 \mathrm{~d}-\mathrm{f}$ \\
\hline & \multirow{4}{*}{$3 \%$} & NK-8441 & $49.7 \pm 1.05$ ef & $8.7 \pm 0.32 \mathrm{jk}$ & $82 \pm 5.351$ & $42 \pm 2.80 \mathrm{k}$ & $66 \pm 4.721$ & $32 \pm 2.17 \mathrm{~m}$ \\
\hline & & P-1543 & $55.2 \pm 1.1 \mathrm{~cd}$ & $10.8 \pm 0.38 \mathrm{~g}-\mathrm{i}$ & $53 \pm 3.19 \mathrm{~m}$ & $27 \pm 2.691$ & $41 \pm 2.89 \mathrm{~m}$ & $21 \pm 1.60 \mathrm{n}$ \\
\hline & & NK-8711 & $44.1 \pm 0.96 \mathrm{gh}$ & $6.5 \pm 0.301$ & $112 \pm 7.02 \mathrm{jk}$ & $56 \pm 2.18 \mathrm{ij}$ & $92 \pm 5.73 \mathrm{jk}$ & $43 \pm 2.13 \mathrm{kl}$ \\
\hline & & FH-985 & $39.0 \pm 0.86 \mathrm{ij}$ & $4.3 \pm 0.29 \mathrm{~m}$ & $141 \pm 5.61 \mathrm{hi}$ & $73 \pm 3.29 \mathrm{gh}$ & $120 \pm 4.16 \mathrm{~g}-\mathrm{i}$ & $56 \pm 1.66 \mathrm{~h}-\mathrm{j}$ \\
\hline \multirow{7}{*}{$\begin{array}{c}\text { S } \\
\text { soil }\end{array}$} & \multirow{4}{*}{$0 \%$} & NK-8441 & $40.4 \pm 0.93 \mathrm{hi}$ & $17.1 \pm 0.49 \mathrm{~b}$ & $233 \pm 5.37 \mathrm{~cd}$ & $103 \pm 3.30 \mathrm{~cd}$ & $185 \pm 4.80 \mathrm{~cd}$ & $81 \pm 1.68 \mathrm{~cd}$ \\
\hline & & P-1543 & $45.6 \pm 1.04 \mathrm{fg}$ & $19.4 \pm 0.52 \mathrm{a}$ & $204 \pm 4.70 \mathrm{e}$ & $88 \pm 2.74$ ef & $155 \pm 4.95$ ef & $68 \pm 2.72 \mathrm{e}-\mathrm{g}$ \\
\hline & & NK-8711 & $34.9 \pm 0.91 \mathrm{jk}$ & $14.9 \pm 0.46 \mathrm{~cd}$ & $263 \pm 6.58 \mathrm{~b}$ & $121 \pm 2.24 b$ & $214 \pm 5.45 b$ & $94 \pm 1.73 \mathrm{~b}$ \\
\hline & & FH-985 & $29.6 \pm 0.85 \mathrm{~lm}$ & $12.8 \pm 0.43 \mathrm{e}-\mathrm{g}$ & $307 \pm 4.89 \mathrm{a}$ & $142 \pm 3.24 \mathrm{a}$ & $251 \pm 4.91 \mathrm{a}$ & $110 \pm 2.51 \mathrm{a}$ \\
\hline & \multirow{3}{*}{$3 \%$} & NK-8441 & $62.2 \pm 1.09 \mathrm{~b}$ & $13.6 \pm 0.41 \mathrm{~d}-\mathrm{f}$ & $174 \pm 4.44 \mathrm{fg}$ & $82 \pm 2.84 \mathrm{fg}$ & $140 \pm 4.83 \mathrm{fg}$ & $64 \pm 2.20 \mathrm{f}-\mathrm{h}$ \\
\hline & & P-1543 & $67.4 \pm 1.06 \mathrm{a}$ & $15.7 \pm 0.43 b c$ & $143 \pm 6.24 \mathrm{hi}$ & $65 \pm 2.07 \mathrm{hi}$ & $110 \pm 3.48 \mathrm{~h}-\mathrm{j}$ & $51 \pm 1.60 \mathrm{i}-\mathrm{k}$ \\
\hline & & NK-8711 & $57.0 \pm 0.96 c$ & $11.4 \pm 0.37 \mathrm{gh}$ & $207 \pm 4.99 \mathrm{de}$ & $99 \pm 2.27 \mathrm{de}$ & $166 \pm 6.37 \mathrm{de}$ & $76 \pm 1.89 \mathrm{de}$ \\
\hline
\end{tabular}

The values are mean \pm S.E. $(n=3)$. Mean values with different alphabetical letters are significantly different $(p<0.05)$ according to Tukey's HSD test; K: Kasur soil; S: Sialkot soil. 




Figure 3. Correlation matrix representing correlation among different attributes of maize crop followed by different treatments, such as Kasur soils (0\% biochar) (1) NK-8441, (2) P-1543, (3) NK-8711, (4) FH-985; (3\% biochar) (5) NK-8441, (6) P-1543, (7) NK-8711, (8) FH-985; Sialkot soils (0\% biochar) (9) NK-8441, (10) P-1543, (11) NK-8711, (12) FH-985; (3\% biochar) (13) NK-8441, (14) P-1543, (15) NK-8711, (16) FH-985. Positive correlations are displayed in blue and negative correlations in red. The color legend on the right-hand side of the correlogram shows the correlation coefficients and the corresponding colors. The abbreviations are as follows: Shoot length: SL, Root length: RL, Shoot dry weight: SDW, Root dry weight: RDW, Chlorophyll contents: SPAD, Photosynthetic rate: PR, Transpiration rate: TR, Stomatal conductance: SC, Lipid peroxidation: LP, Proline contents: PL, Total carotenoids: CR, Soil Cr 1ll: SCrlll, Shoot Cr III: SHCrIII, Root Cr III: RCrIII, Soil Cr VI: SCrVl, Shoot Cr VI: SHCrVI, Root Cr VI: RCrVI, Relative water contents: RWC, Electrolyte leakage: ELC, Catalase: CAT, Ascorbate peroxidase: ASC, Glutathione peroxidase: GP, Soluble sugars: SS, and Superoxide dismutase: SOD. 


\section{PCA - Biplot}

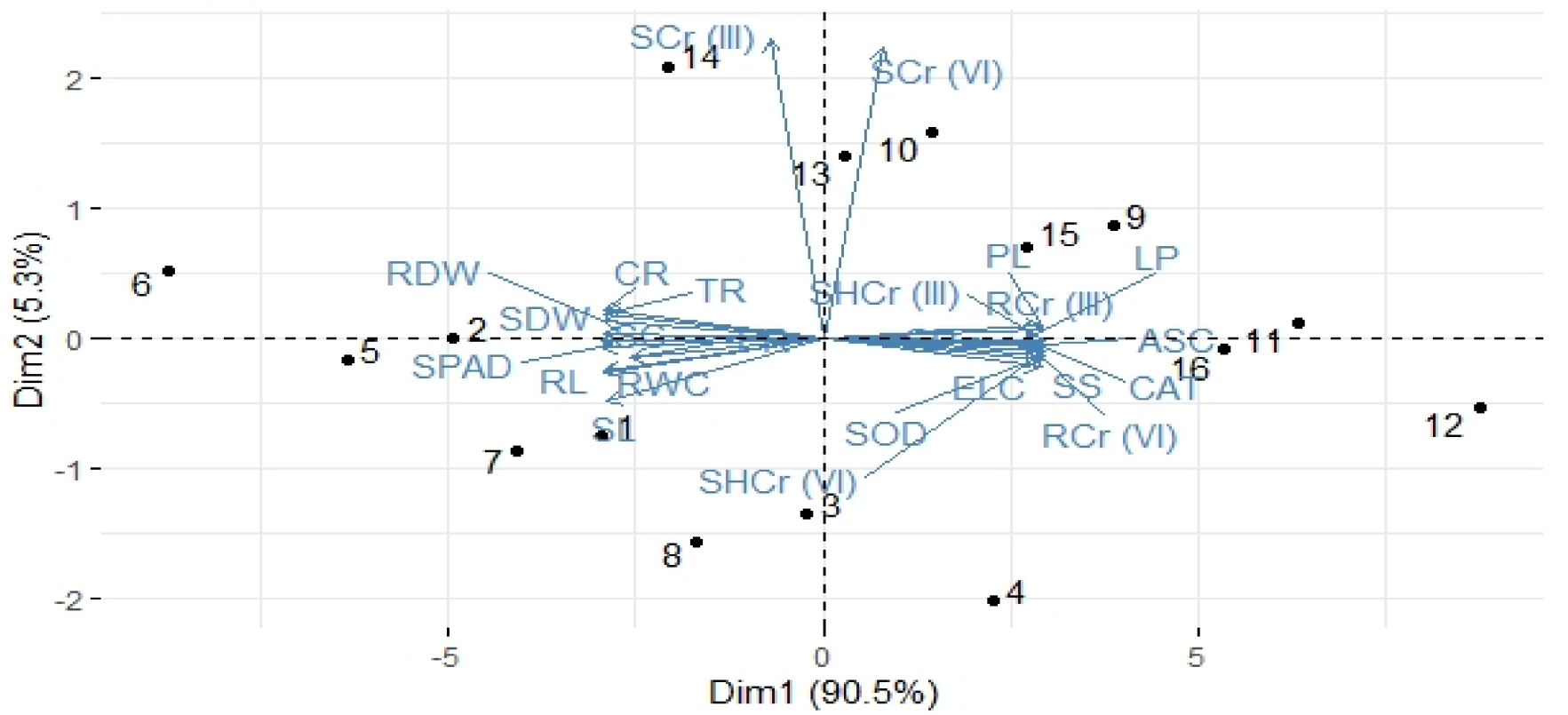

Figure 4. Principal component analysis (PCA) showing biplot (score and loading) of different attributes of maize cultivars. Score plot represents separation of treatments, such as Kasur soils ( $0 \%$ biochar) (1) NK-8441, (2) P-1543, (3) NK-8711, (4) FH-985; (3\% biochar) (5) NK-8441, (6) P-1543, (7) NK-8711, (8) FH-985; Sialkot soils (0\% biochar) (9) NK-8441, (10) P-1543, (11) NK-8711, (12) FH-985; (3\% biochar) (13) NK-8441, (14) P-1543, (15) NK-8711, (16) FH-985. Loading plot shows the loading of each studied variable (arrows) and the arrow length approximates their variance, whereas the angles between them represent their correlation. The abbreviations are as follows: Shoot length: SL, Root length: RL, Shoot dry weight: SDW, Root dry weight: RDW, Chlorophyll contents: SPAD, Photosynthetic rate: PR, Transpiration rate: TR, Stomatal conductance: SC, Lipid peroxidation: LP, Proline contents: PL, Total carotenoids: CR, Soil Cr 1ll: SCrlll, Shoot Cr III: SHCrIII, Root Cr III: RCrIII, Soil Cr VI: SCrVl, Shoot Cr VI: SHCrVI, Root Cr VI: RCrVI, Relative water contents: RWC, Electrolyte leakage: ELC, Catalase: CAT, Ascorbate peroxidase: ASC, Glutathione peroxidase: GP: Soluble sugars: SS, and Superoxide dismutase: SOD.

\section{Discussion}

Soil pollution caused by the utilization of heavy metal in chemical-based manufacturing industries is a growing problem all over the world. In Pakistan, the lack of policies and their improper implementation has dramatically increased the heavy metal pollution from industries [81]. It is an established fact that low organic matter and $\mathrm{Cr}$ accumulation may disturb the soil structure and results in reduced crop growth [82]. Biochar is a recalcitrant carbonaceous charred organic amendment that has the potential to improve soil structure, organic matter, water holding capacity, and nutrient retention in the soil $[83,84]$. Owing to its large surface area, various functional groups and high CEC biochar could act as an adsorbent material for heavy metal clean-up from the contaminated sites [85-87].

In the present study, potential of biochar was compared on $\mathrm{Cr}$ accumulation, improvement in growth, physiology, and biochemistry of maize cultivars (NK-8441, P-1543, NK-8711, and FH-985) vegetated in soils polluted with tannery waste produced by tannery industrial complex in two districts of Punjab (Kasur and Sialkot), Pakistan. The results of the present study revealed that the $\mathrm{Cr}$ toxicity in tannery waste polluted $\mathrm{K}$ and $\mathrm{S}$ soils have strongly negatively affected the development and growth of maize cultivars. However, the magnitude of toxicity caused by $\mathrm{Cr}$ and its effects on maize cultivars varied in both soils. Maize growth was more affected in $\mathrm{S}$ soil as related to $\mathrm{K}$ soil. This effect might be related to greater $\mathrm{Cr}$ toxicity of S soil. Similarly, alteration in plant physiological processes due to $\mathrm{Cr}$ toxicity was also monitored, which might be involved in the growth and improvement of maize cultivars. This variable response of plants in their various growth and development 
phases under heavy metal $\mathrm{Cr}$ toxicity are in accordance with earlier studies $[6,14,17,27]$. The reduction in root growth under the influence of $\mathrm{Cr}$ could be attributed to inhibited root cell division, elongation, and/or an affected cell cycle [88]. Chromium stress probably has decreased the root surface for soil penetration and plant ability to explore the soil surface for water [89,90]. Exposure of seedling roots with $\mathrm{Cr}$ most likely has caused tissue collapse, and consequently, failure to absorb water and nutrients, and ultimately stunted plant growth $[17,91]$. Moreover, localization of $\mathrm{Cr}$ into vacuoles, particularly in parenchyma cells and cell walls of xylem perhaps has affected cell activity and might have lowered the water potential $[92,93]$. Similarly, reduced plant height and shoot weight might have attributed to reduced root growth and subsequently lowered nutrient and water transport to the aerial part [94]. In addition, $\mathrm{Cr}$ translocation from root to shoot might have affected the cellular metabolism of shoots and reduced the shoot growth [95].

Development of leaf area, growth, and total number of leaves aggressively direct the plant growth and its development. The reduction in leaf area could be related to structural abnormalities, chlorosis, and/or tissue necrosis because of $\mathrm{Cr}$ toxicity [96]. The addition of biochar gave better results in terms of improved plant growth and physiological attributes. This improvement might be associated to high surface area of biochar that have sorbed most of the $\mathrm{Cr}$ and lowered its availability and toxicity for plant growth and development [87,97]. Similar results regarding improvement in plant growth by application of biochar in lead $(\mathrm{Pb})$ contaminated soil were observed by Jiang et al. [98]. A reduction in the available portion of cadmium $(\mathrm{Cd})$, zinc $(\mathrm{Zn})$, and $\mathrm{Pb}$ due to biochar $(10 \%)$ application was reported by Houben et al. [36]. In our results, $\mathrm{Cr}$ toxicity have affected the growth of maize cultivars and it was observed in the order P-1543 > NK-8441 > NK-8711 > FH-985. Cultivar P-1543 was less affected in both soils showed the better performance by resistivity against $\mathrm{Cr}$ stress, whereas the growth of maize cultivar FH-985 was maximally affected, indicating sensitivity to $\mathrm{Cr}$ toxicity. It is well known that biochar application results in the supply of crop nutrients for a longer time, and thus, improve the growth and productivity of crops under stressed conditions $[39,99,100]$.

The positive effects of biochar were also observed in terms of improved plant physiological process. Photosynthetic pigments, i.e., SPAD chlorophyll, chlorophyll "a" and " $b$ " as well as total carotenoids, are molecules involved to capture light energy of definite wavelength essential for photosynthesis and were affected by $\mathrm{Cr}$ stress in $\mathrm{K}$ and $\mathrm{S}$ soil. Impaired activities of enzymes involved in the biosynthesis of pigments and reduction in uptake of magnesium $(\mathrm{Mg})$ and nitrogen $(\mathrm{N})$ due to $\mathrm{Cr}$ toxicity could be a reason of reduced photosynthetic pigments [101,102]. Moreover, it might also be associated with the increased production of ROS that results in lowering the photosynthetic capacity of the plants under Cr stress [103]. Chromium accumulation might also have reduced the energy utilization, which in turn reduced the activity of photosynthetic pigments [104,105]. Similarly, the plant photosynthetic rate (A) in terms of the $\mathrm{CO}_{2}$ fixation rate was significantly decreased by $\mathrm{Cr}$ toxicity of $\mathrm{K}$ and $\mathrm{S}$ soil. Harmful influence of $\mathrm{Cr}$ probably has affected the activities of carbon fixation enzymes and electron transport chain [106]. Reduced $\mathrm{CO}_{2}$ assimilation might also be related to low efficiency in excitation capture and PS-II quantum yield [107,108]. Chromium-induced abnormalities also affected the plant transpiration rate (E) with respect to water loss from plant surfaces. The reduction in the transpiration rate may possibly be attributed to reduced water potential and enhanced diffusive resistance [109]. Similarly, stomata, having special cells known as guard cells, control its opening and closing [110]. These stomatal openings endure gas exchange at the cost of water loss and are affected by toxic Cr influence [108]. Our results are in accordance with previous reports [15,91], in which reduced physiological and photosynthetic ability of plants grown under Cr stress was also observed.

The bioaccumulation of toxic $\mathrm{Cr}$ metal might have reduced the cell osmotic potential or reduced nutrient uptake and caused an imbalance of the stomatal activity, and therefore, affected plant photosynthetic process and reduced plant growth [111]. In the photosynthetic pigments, $\mathrm{Cr}$ toxicity might also have decreased the size of the peripheral part of the 
antenna complex, degradation or destabilization of the proteins of the peripheral part, or inactivation of enzymes that could lead to decline in chlorophyll content $[112,113]$. Reduced synthesis of chlorophyll, ultra-structure of chloroplast disorganization, inhibition of electron transport processes, and/or decreased enzymatic activity of Calvin cycle by Cr stress [17] could be possible reasons of the decreased plant photosynthetic process in the present study. In photochemical process, the synthesis of electron may not be efficiently utilized for carbon assimilation; deviation of electrons of PS-I to Cr (VI) in the electron donating side $[13,106]$ could also be a reason of reduced photosynthetic rate, as was evidenced in our results for $\mathrm{Cr}$ toxicity. Chromium-induced abnormalities in the ultrastructure of chloroplast could be caused by a poorly created lamellar system with broadly separated thylakoid and little grana [114]. The decrease in relative water content may be due to the reduced root surface and area that might have reduced the plant potential to absorb the water from soil surface [115]. In addition, the $\mathrm{Cr}$ toxicity in the plant might also have reduced the longitudinal water movement by decreasing the diameter of treachery vessel [17]. Similarly, ROS are generated as a normal product of plant cellular metabolism. These consist of free radicals such as hydroxyl radical $\left({ }^{\bullet} \mathrm{OH}\right)$ and superoxide anion $\left(\mathrm{O}_{2}{ }^{-}-\right)$in addition to non-radical molecules such as singlet oxygen $\left({ }^{1} \mathrm{O}_{2}\right)$, hydrogen peroxide $\left(\mathrm{H}_{2} \mathrm{O}_{2}\right)$, and so forth $[116,117]$. Chromium stress in plants leads to production of excessive ROS due to cellular homeostasis disruption [118]. Excessive formation of ROS causes oxidative damage in plants, including cell membrane damage and leakage of cell electrolytes [14]. Moreover, enhanced EL in this study might be associated to excessive ROS formation by $\mathrm{Cr}$ stress. However, the application of biochar resulted in increased RWC and decreased EL, which might be associated to enhanced availability of essential plant nutrients and improved water holding capacity $[32,52,119]$. The increased RWC and decreased EL, thus, helped to better sustain maize cultivars under Cr stressed environments $[15,120]$.

Stress-related metabolites, such as the accumulation of soluble sugars, lipid peroxidation, proline, etc., may play a role in inducing resistance to stress by avoiding cell damage against attacks by free radicals [121,122]. An increased content of these metabolites in plants have been reported by environmental stresses such as salinity, drought, temperature, and heavy metals toxicity [123]. The accumulation of proline has multiple functions, such as osmotic adjustment, enzyme protection, detoxification of injurious ROS, and maintaining protein synthesis $[124,125]$. In the present study, an increased level of proline content has been observed, which might be associated to a plant's adopted strategies to survive with Cr toxicity [113]. In the same way, an increased level of soluble sugars in plants has also been indicated in various stress conditions [126]. In this study, the accumulation of soluble sugars that was monitored may be due to the increased concentration of $\mathrm{Cr}$ in the plant tissues. The accumulation of soluble sugars in the stress form protects and repairs the biomolecules and cell membranes [125]. In addition, soluble sugars in the stress environment could help to retain cell osmotic potential and maintains carbohydrate supplement [122]. Similarly, lipid peroxidation is a chain reaction and is formed by oxidative damage of ROS, which affects cellular membranes, lipoproteins, and other molecules that contain lipids [127]. Here, the increased level of lipid peroxidation in the form of MDA content might be associated to the oxidative damage of $\mathrm{Cr}$.

The detrimental effects of $\mathrm{Cr}$ also altered the extent of antioxidant enzymes activities in both soils. Undeniably, the enhancement in activities of APX, GPX, CAT, and SOD enzymes of maize leaves was observed under Cr-polluted soils, which suggests its role in the detoxification of ROS. These results were supported by previous findings $[15,100,128]$. Susceptible genotypes (FH-985) showed more increase in antioxidants activity compared to tolerant genotypes (P-1543). Similar findings were previously reported by Foroozesh [129] on antioxidant enzyme activity in different bean genotypes against $\mathrm{Cd}$ stress. Increased activity of APX might play a function in scavenging of $\mathrm{H}_{2} \mathrm{O}_{2}$ and converting it into water by using ascorbate as an electron donor [118,130]. Enhanced activity of GPX might have protected the protein and lipid membrane against denaturation caused by $\mathrm{Cr}$ exposure $[15,131]$. 
Similarly, higher activity of CAT lessened the oxidative effect of $\mathrm{Cr}$ metal to stromal and thylakoid of chloroplast function [106,132]. Elevated activity of SOD most likely formed primary resistance against oxidative damage and altered $\mathrm{O}_{2}{ }^{-}$to $\mathrm{H}_{2} \mathrm{O}_{2}$, which subsequently further transformed it into water by APX and CAT [15,113].

Chromium (VI) and (III) accumulation in maize cultivars were also quite different in both soils. Basic analysis of soils (Table 2) revealed that $\mathrm{S}$ soil has higher $\mathrm{Cr}$ concentration, and consequently, accumulated more $\mathrm{Cr}$ in maize plant (root and shoot). The highest accumulation of $\mathrm{Cr}$ was found in cultivar FH-985, which might be associated to its sensitiveness against stress. Structural resemblance of $\mathrm{Cr}$ with some essential elements can displace plant mineral nutrient uptake and translocation in a complicated way. The decrease in nutrient uptake in plants could also be due to reduced root growth and its surface $[133,134]$. Chromium (III and VI) accumulation in plant usually takes place by different mechanisms. In the tannery industry, primarily $\mathrm{Cr}$ (III) is released through waste effluent and converted into Cr (VI) under oxidized conditions $[15,30,135]$. Higher accumulation of Cr (III) in plants, as was observed in our results, could be associated to higher $\mathrm{Cr}$ (III) concentration in soil compared to $\mathrm{Cr}(\mathrm{VI})$. Moreover, $\mathrm{Cr}$ (III) is most likely passively taken up in plants by simple diffusion, whereas $\mathrm{Cr}(\mathrm{VI})$ is usually actively taken up in plants by metabolically driven processes consisting of carriers of essential anions such as sulfate $\left(\mathrm{SO}_{4}{ }^{-}\right)[27,136]$. Furthermore, reduction of $\mathrm{Cr}$ (VI) into $\mathrm{Cr}$ (III) in the plant could also be a reason of greater $\mathrm{Cr}$ (III) concentration. Most of the $\mathrm{Cr}$ accumulated in plant roots and a little fraction is transported to the aerial part [106], as was observed in the present study. A low concentration of $\mathrm{Cr}$ in shoot compared to root could be due to complexation, sequestration, or compartmentalization in the cytoplasm and vacuoles of the root cells $[137,138]$. Chromium also attached to exchange receptors and became immobile in the roots. The least mobility or poor translocation of $\mathrm{Cr}$ in root caused greater accumulation of $\mathrm{Cr}$ in root cells [112]. A contradiction of $\mathrm{Cr}$ uptake and translocation in the plants are also present. Some authors stated that $\mathrm{Cr}$ is reduced from hexavalent form to trivalent form in the plant $[13,139,140]$, while others reported that $\mathrm{Cr}(\mathrm{VI})$ is directly taken up and translocated by plants without its reduction [17,137]. Moreover, the reduction of $\mathrm{Cr}$ (VI) into $\mathrm{Cr}$ (III) in the plants led to the generation of ROS, which also affected the growth of the plant.

The application of biochar significantly reduced the $\mathrm{Cr}$ (VI) (available fraction) concentration and increased the $\mathrm{Cr}$ (III) concentration in soil, which consequently reduced the accumulation of $\mathrm{Cr}$ in aerial part. The improved effect of biochar could be attributed to a reduced $\mathrm{Cr}$ uptake in a plant by adsorption on its surface, precipitation, or complex formation leading to enhanced plant growth $[32,84,141]$. The surface of biochar is usually negatively charged, but it also has positive surface charges [142,143]. The enhanced effect by the addition of biochar could be associated to sorption of $\mathrm{Cr}$ (III and VI) on the charged surface of biochar through electrostatic attractions $[12,144]$. The mineral component of biochar, i.e., oxidates, phosphates, or carbonates, are most likely involved in the formation of various precipitates of $\mathrm{Cr}$, and therefore, might have reduced their bioavailability [83,85]. Oxygen- and hydrogen-containing functional groups present on the surface of biochar probably have interacted with $\mathrm{Cr}$ and might have formed complexation and lowered its availability to the plant body [32,84]. Moreover, biochar might also have reduced the $\mathrm{Cr}$ (VI) into harmless and less soluble/mobile Cr (III), by donating electrons or through adsorption coupled reduction [36,145-147]. In conclusion, cultivar P-1543 performed better over other cultivars (NK-8441, NK 8711, and FH-985) by reduced uptake of $\mathrm{Cr}$ in the aerial part of plant, which indicated resistance/tolerance against $\mathrm{Cr}$ stress.

\section{Conclusions}

Biochar (3\%) application significantly improved the physiology, biochemistry, antioxidant activity, and overall growth and health of maize plants along with a significant reduction in the level of $\mathrm{Cr}$ (VI and III) accumulation under tannery polluted Kasur and Sialkot soils. The extent of $\mathrm{Cr}$ toxicity, accumulation, and its effects on growth of maize cultivars (NK-8441, P-1543, NK-8711, and FH-985) varied in both soils, and cultivar P-1543 
performed better in a stressed environment. Biochar application could be a better approach in order to reduce the $\mathrm{Cr}$ toxicity level in tannery polluted soils for the enhancement of growth, physio-biochemical characteristics, and production yield of maize plants. In general, biochar application can ameliorate the consequence of soil contamination caused by industrial waste material.

Author Contributions: Conceptualization: M.N. and X.W.; Methodology: M.A.B., M.N., A.M.; Software: A.M. and T.S.; validation: M.N. and X.W.; Data curation: M.A.B.; Formal analysis: A.M., T.S., S.M.N. and S.A.; Investigation: M.N. and M.A.B.; Resources: M.N. and M.J., Supervision: M.N.; funding acquisition: M.N. and X.W.; Writing—original draft preparation: M.A.B.; Writing—review \& editing: M.N., M.J., X.W. and S.M.N. All authors have read and agreed to the published version of the manuscript.

Funding: This research received financial support from Higher Education (HEC) Pakistan via NRPU project No: 6443/Punjab/NRPU/R\&D/HEC/2016.

Institutional Review Board Statement: Not applicable.

Informed Consent Statement: Not applicable.

Data Availability Statement: The data presented in this study are available on request from the corresponding author.

Acknowledgments: The authors are grateful to the Institute of Soil \& Environmental Sciences, University of Agriculture, Faisalabad, Pakistan and College of Life Sciences, Yan'an University, Yan'an, China for providing research facilities and support.

Conflicts of Interest: The authors declare no conflict of interest.

\section{References}

1. Athar, R.; Ahmad, M. Heavy metal toxicity: Effect on plant growth and metal uptake by wheat, and on free living azotobacter. Water Air Soil Pollut. 2002, 138, 165-180. [CrossRef]

2. Baran, A.; Wieczorek, J. Application of geochemical and ecotoxicity indices for assessment of heavy metals content in soils. Arch. Environ. Protect. 2015, 41, 53-62. [CrossRef]

3. Turan, V.; Khan, S.A.; Mahmood-ur-Rahman; Iqbal, M.; Ramzani, P.M.A.; Fatima, M. Promoting the productivity and quality of brinjal aligned with heavy metals immobilization in a wastewater irrigated heavy metal polluted soil with biochar and chitosan. Ecotoxicol. Environ. Saf. 2018, 161, 409-419. [CrossRef] [PubMed]

4. Syed, M.; Saleem, T.; Shuja-ur-Rehman; Iqbal, M.A.; Javed, F.; Khan, M.B.; Sadiq, K. Effects of leather industry on health and recommendations for improving the situation in Pakistan. Arch. Environ. Occup. Health 2010, 65, 163-172. [CrossRef]

5. Ertani, A.; Mietto, A.; Borin, M.; Nardi, S. Chromium in agricultural soils and crops: A review. Water Air Soil Pollut. 2017, 228, 190. [CrossRef]

6. Bashir, M.A.; Khalid, M.; Naveed, M.; Ahmad, R.; Gao, B. Influence of feedstock and pyrolytic temperature of biochar on physico-chemical characteristics and sorption of chromium in tannery polluted soil. Int. J. Agric. Biol. 2018, 20, $2823-2834$.

7. Azom, M.R.; Mahmud, K.; Yahya, S.M.; Sontu, A.; Himon, S.B. Environmental impact assessment of tanneries: A case study of Hazaribag in Bangladesh. Int. J. Environ. Sci. Dev. 2012, 3, 152-156. [CrossRef]

8. Rashid, H.; Takemura, J.; Farooqi, A.M. Investigation of subsurface contamination due to chromium from tannery effluent in Kasur District of Pakistan. J. Environ. Sci. Eng. 2012, 1, 1007-1024.

9. Yasin, M.; Faisal, M. Assessing the phytotoxicity of tannery waste-contaminated soil on Zea mays (Lin) Growth. Pol. J. Environ. Stud. 2013, 22, 1871-1876.

10. Wionczyk, B.; Apostoluk, W.; Charewicz, W.A. Solvent extraction of chromium (III) from spent tanning liquors with Aliquat 336. J. Hydrometall. 2006, 82, 83-92. [CrossRef]

11. Ghani, A. Effect of chromium toxicity on growth, chlorophyll and some mineral nutrients of Brassica juncea L. Egypt. Acad. J. Biol. Sci. H. Bot. 2011, 2, 9-15.

12. Nigussie, A.; Kissi, E.; Misganaw, M.; Ambaw, G. Effect of biochar application on soil properties and nutrient uptake of lettuces (Lactuca sativa) grown in chromium polluted soils. Am.-Eurasian J. Agric. Environ. Sci. 2012, 12, 369-376.

13. Singh, H.P.; Mahajan, P.; Kaur, S.; Batish, D.R.; Kohli, R.K. Chromium toxicity and tolerance in plants. Environ. Chem. Lett. 2013, 11, 229-254. [CrossRef]

14. Oancea, S.; Foca, N.; Airinel, A. Effect of heavy metal on plant growth and photosynthetic activity. Analele Ştiintifice Ale Universitatii IAŞI 2005, 5, 107-110. 
15. Bashir, M.A.; Naveed, M.; Ahmad, Z.; Gao, B.; Mustafa, A.; Nú nez-Delgado, A. Combined application of biochar and sulfur regulated growth, physiological, antioxidant responses and $\mathrm{Cr}$ removal capacity of maize (Zea mays L.) in tannery polluted soils. J. Environ. Manag. 2020, 259, 110051. [CrossRef]

16. Pandey, V.; Dixit, V.; Shyam, R. Chromium (VI) induced changes in growth and root plasma membrane redox activities in pea plants. Protoplasma 2009, 235, 49-55. [CrossRef] [PubMed]

17. Shanker, A.K.; Cervantesb, C.; Loza-Taverac, H.; Avudainayagam, S. Chromium toxicity in plants, Review Article. Environ. Int. 2005, 31, 739-753. [CrossRef]

18. Ghani, A. Toxic effects of heavy metals on plant growth and metal accumulation in maize (Zea mays L.). Iranian J. Toxicol. 2010, 3 , 325-334.

19. Pan, J.; Jiang, J.; Xu, R. Adsorption of Cr (III) from acidic solutions by crop straw derived biochars. J. Environ. Sci. 2013, 25, 1957-1965. [CrossRef]

20. Mandal, B.K.; Suzuki, K.T. Arsenic round the world: A review. Talanta 2002, 58, 201-235. [CrossRef]

21. Guo, H.; Stuben, D.; Berner, Z. Arsenic removal from water using natural iron mineral-quartz sand columns. Sci Total Environ. 2007, 377, 142-151. [CrossRef] [PubMed]

22. Singh, R.; Gautam, N.; Mishra, A.; Gupta, R. Heavy metals and living systems: An overview. Indian J. Pharmacol. 2011, 43, 246-253. [CrossRef]

23. Kotaś, J.; Stasicka, Z. Chromium occurrence in the environment and methods of its speciation. Environ. Pollut. 2000, 107, 263-283. [CrossRef]

24. Mohan, D.; Rajput, S.; Singh, V.K.; Steele, P.H.; Pittman, C.U. Modeling and evaluation of chromium remediation from water using low cost biochar, a green adsorbent. J. Hazard. Mater. 2011, 188, 319-333. [CrossRef] [PubMed]

25. Adriano, D.C. Trace elements in terrestrial environments. In Biogeochemistry, Bioavailability, and Risks of Metals, 2nd ed.; Springer: New York, NY, USA, 2001.

26. Agrafioti, E.; Kalderis, D.; Diamadopoulos, E. Arsenic and chromium removal from water using biochars derived from rice husk, organic solid wastes and sewage sludge. J. Environ. Manag. 2014, 133, 309-314. [CrossRef]

27. Cervantes, C.; Campos-Garcia, J.; Devars, S.; Gutierrez-Corona, F.; Loza-Tavera, H.; Torres-Guzman, J.C.; Moreno-Sanchez, R. Interactions of chromium with microorganisms and plants. FEMS Microbiol. Rev. 2001, 25, 335-347. [CrossRef] [PubMed]

28. Das, N.; Mathew, L. Chromium pollution and bioremediation: An Overview. Biomanag. Met.-Contam. Soils 2011, 20, 297-321. [CrossRef]

29. Dong, X.; Ma, L.Q.; Li, Y. Characteristics and mechanisms of hexavalent chromium removal by biochar from sugar beet tailing. J. Hazard. Mater. 2011, 190, 909-915. [CrossRef]

30. Razic, S.; Dogo, S. Determination of chromium in Mentha piperita L. and soil by graphite furnace atomic absorption spectrometry after sequential extraction and microwave-assisted acid digestion to assess potential bioavailability. Chemosphere 2011, 78, 451-456. [CrossRef]

31. Costa, M.; Klein, C.B. Toxicity and carcinogenicity of chromium compounds in humans. Crit. Rev. Toxicol. 2006, 36, 155-163. [CrossRef] [PubMed]

32. Beesley, L.; Inneh, O.S.; Norton, G.J.; Moreno-Jimenez, E.; Pardo, T.; Clemente, R.; Dawson, J.J.C. Assessing the influence of compost and biochar amendments on the mobility and toxicity of metals and arsenic in a naturally contaminated mine soil. Environ. Pollut. 2014, 186, 195-202. [CrossRef] [PubMed]

33. Hartley, W.; Dickinson, N.M.; Riby, P.; Lepp, N.W. Arsenic mobility in brownfield soils amended with greenwaste compost or biochar and planted with Miscanthus. Environ. Pollut. 2009, 157, 2654-2662. [CrossRef]

34. Clemente, R.; Walker, D.J.; Pardo, T.; Martínez-Fernández; Bernal, M.P. The use of halophytic plant species and organic amendments for the remediation of a trace elements-contaminated soil under semi-arid conditions. J. Hazard. Mater. 2012, 223-224, 63-71. [CrossRef]

35. Mustafa, A.; Minggang, X.; Shah, S.A.A.; Abrar, M.M.; Nan, S.; Baoren, W.; Zejiang, C.; Saeed, Q.; Naveed, M.; Mehmood, K.; et al. Soil aggregation and soil aggregate stability regulate organic carbon and nitrogen storage in a red soil of southern China. J. Environ. Manag. 2020, 270, 110894. [CrossRef]

36. Houben, D.; Evrard, L.; Sonnet, P. Mobility, bioavailability and pH-dependent leaching of cadmium, zinc and lead in a contaminated soil amended with biochar. Chemosphere 2013, 92, 1450-1457. [CrossRef]

37. Karami, N.; Clemente, R.; Jimenez, E.M.; Lepp, N.W.; Beesley, L. Efficiency of green waste compost and biochar soil amendments for reducing lead and copper mobility and uptake to ryegrass. J. Hazard. Mater. 2011, 191, 41-48. [CrossRef]

38. Karer, J.A.; Wawra, F.; Zehetner, G.; Dunst, M.; Wagner, P.; Pavel, M.; Puschenreiter, W.; Friesl-Hanl; Soja, G. Effects of biochars and compost mixtures and inorganic additives on immobilisation of heavymetals in contaminated soils. Water Air Soil Pollut. 2015, 226, 3-12. [CrossRef]

39. Kamran, M.; Malik, Z.; Parveen, A.; Zong, Y.; Abbasi, G.H.; Rafiq, M.T.; Shaaban, M.; Mustafa, A.; Bashir, S.; Rafay, M.; et al. Biochar alleviates $\mathrm{Cd}$ phytotoxicity by minimizing bioavailability and oxidative stress in pak choi (Brassica chinensis L.) cul-tivated in Cd-polluted soil. J. Environ. Manag. 2019, 250, 109500. [CrossRef] [PubMed]

40. Baigorri, R.; San Francisco, S.; Urrutia, Ó.; García-Mina, J.M. Biochar-Ca and Biochar-Al/-Fe-Mediated Phosphate Exchange Capacity are Main Drivers of the Different Biochar Effects on Plants in Acidic and Alkaline Soils. Agronomy 2020, 10, 968. [CrossRef] 
41. Ahmad, M.; Wang, X.; Hilger, T.H.; Luqman, M.; Nazli, F.; Hussain, A.; Zahir, Z.A.; Latif, M.; Saeed, Q.; Malik, H.A.; et al. Evaluating Biochar-Microbe Synergies for Improved Growth, Yield of Maize, and Post-Harvest Soil Characteristics in a Semi-Arid Climate. Agronomy 2020, 10, 1055. [CrossRef]

42. Sohi, S.P.; Krull, E.; Lopez-Capel, E.; Bol, R. A review of biochar and its use and function in soil. In Advances in Agronomy; Sparks, D.L., Ed.; Academic Press: Burlington, MA, USA, 2010; Volume 105, pp. 47-82.

43. Chen, B.L.; Yuan, M.X. Enhanced sorption of polycyclic aromatic hydrocarbons by soil amended with biochar. J. Soils Sediments 2011, 11, 62-71. [CrossRef]

44. Lu, H.; Zhang, W.; Yang, Y.; Huang, X.; Wang, S.; Qiu, R. Relative distribution of $\mathrm{Pb}^{2+}$ sorption mechanisms by sludge-derived biochar. Water Res. 2012, 46, 854-862. [CrossRef]

45. Al-Wabel, M.I.; Usman, A.R.; El-Naggar, A.H.; Aly, A.A.; Ibrahim, H.M.; Elmaghraby, S.; Al-Omran, A. Conocarpus biochar as a soil amendment for reducing heavy metal availability and uptake by maize plants. Saudi J. Biol. Sci. 2015, 22, 503-511. [CrossRef]

46. Uchimiya, M.; Chang, S.C.; Klasson, K.T. Screening biochars for heavy metal retention in soil: Role of oxygen functional groups. J. Hazard. Mater. 2011, 190, 432-444. [CrossRef]

47. Choppala, G.; Bolan, N.; Kunhikrishnan, A.; Bush, R. Differential effect of biochar upon reduction-induced mobility and bioavailability of arsenate and chromate. Chemosphere 2016, 144, 374-381. [CrossRef]

48. Liu, H.; Liang, S.; Gao, J.; Ngo, H.H.; Guo, W.; Guo, Z.; Wang, J.; Li, Y. Enhancement of Cr (VI) removal by modifying activated carbon developed from Zizania caduciflora with tartaric acid during phosphoric acid activation. Chem. Eng. J. 2014, 246, 168-174. [CrossRef]

49. Mandal, S.; Sarkar, B.; Bolan, N.; Ok, Y.S.; Naidu, R. Enhancement of chromate reduction in soils by surface modified biochar. J. Environ. Manag. 2017, 186, 277-284. [CrossRef] [PubMed]

50. Schulz, H.; Dunst, G.; Glaser, B. Positive effects of composted biochar on plant growth and soil fertility. Agron. Sustain. Dev. 2013, 33, 817-827. [CrossRef]

51. Naveed, M.; Mustafa, A.; Azhar, S.Q.T.A.; Kamran, M.; Zahir, Z.A.; Núñez-Delgado, A. Burkholderia phytofirmans PsJN and tree twigs derived biochar together retrieved $\mathrm{Pb}$-induced growth, physiological and biochemical disturbances by minimizing its uptake and translocation in mung bean (Vigna radiata L.). J. Environ. Manag. 2020, 257, 109974. [CrossRef] [PubMed]

52. Naveed, M.; Mustafa, A.; Majeed, S.; Naseem, Z.; Saeed, Q.; Khan, A.; Nawaz, A.; Baig, K.S.; Chen, J.T. Enhancing cadmium tolerance and pea plant health through Enterobacter sp. MN17 inoculation together with biochar and gravel sand. Plants 2020, 9, 530. [CrossRef]

53. Wang, H.; Zhang, M.; Li, H. Synthesis of nanoscale zerovalent iron (nZVI) supported on biochar for chromium remediation from aqueous solution and soil. Int. J. Environ. Res. Public Health 2019, 16, 4430. [CrossRef]

54. Sanchez, M.E.; Lindao, E.; Margaleff, D.; Martınez, O.; Moran, A. Pyrolysis of agricultural residues from rape and sunflowers: Production and characterization of bio-fuels and biochar soil management. J. Anal. Appl. Pyrol. 2009, 85, 142-144. [CrossRef]

55. Rajkovich, S.; Enders, A.; Hanley, K.; Hyland, C.; Zimmerman, A.R.; Lehmann, J. Corn growth and nitrogen nutrition after additions of biochars with varying properties to a temperate soil. Biol. Fert. Soils. 2012, 48, 271-284. [CrossRef]

56. Gaskin, J.W.; Steiner, C.; Harris, K.; Das, K.C.; Bibens, B. Effect of low-temperature pyrolysis conditions on biochar for agricultural use. Trans. ASABE 2008, 51, 2061-2069. [CrossRef]

57. Slattery, W.J.; Ridely, A.M.; Windsor, S.M. Ash alkalinity of animal and plant products. Aust. J. Exp. Agric. 1991, 31, 321-324. [CrossRef]

58. Brunauer, S.; Emmett, P.H.; Teller, E. Adsorption of gases in multi molecular layers. J. Am. Chem. Soc. 1938, 60, 309-319. [CrossRef]

59. Enders, A.; Lehmann, J. Comparison of wet-digestion and dry-ashing methods for total elemental analysis of biochar. Commun. Soil Sci. Plant Anal. 2012, 43, 1042-1052. [CrossRef]

60. Gee, G.W.; Bauder, J.W. Particle-size analysis. In Methods of Soil Analysis. Part 1: Physical and Mineralogical Methods, 2nd ed.; Agronomy Monographs 9; Klute, A., Ed.; American Society of Agronomy: Madison, WI, USA, 1986; pp. $383-411$.

61. Sumner, M.E.; Miller, W.P. Cation exchange capacity and exchange coefficients. In Methods of Soil Analysis, Part 3. Chemical Methods; Sparks, D.L., Ed.; American Society of Agronomy: Madison, WI, USA, 1996; pp. 1201-1230.

62. Leoppert, R.H.; Hallmark, C.T.; Koshy, M.M. Routine procedure for rapid determination of soil carbonates. J. Soil Sci. Soc. Am. 1984, 48, 1030-1033. [CrossRef]

63. Jackson, M.L. Soil Chemical Analysis; Printee Hall Inc.: Englewood Cliffs, NJ, USA, 1962.

64. Olsen, S.R.; Sommers, L.E. Phosphours. In Methods of Soil Analysis, Part 2, Chemical and Microbiological Properties, 2nd ed.; Agronomy Monographs 9; Page, A.L., Ed.; American Society of Agronomy: Madison, WI, USA, 1982; pp. $403-430$.

65. Richards, L.A. Diagnosis and Impovement of Saline and Alkali Soil; USDA Agric. Handbook 60; USDA: Washington, DC, USA, 1954.

66. Soon, Y.K.; Abboud, S. Cadmium, chromium, lead and nickel. In Soil Sampling and Methods of Analysis; Carter, M.R., Ed.; Lewis: Boca Raton, FL, USA, 2007; pp. 101-108.

67. Bartlett, R.; James, B. Behaviour of chromium in soils: III. Oxidation. J. Environ. Qual. 1993, 8, 31-35. [CrossRef]

68. Menden, E.E.; Rutland, F.H.; Kallenberger, W.E. Determination of Cr (VI) in tannery waste by the chelation-extraction method. J. Am. Leather Chem. Assoc. 1990, 85, 363-375.

69. Chanda, S.V.; Singh, Y.D. Estimation of leaf area in wheat using linear measurements. Plant Breed. Seed Sci. 2002, 46, 75-79.

70. Sumanta, N.; Haque, C.I.; Nishika, J.; Suprakash, R. Spectrophotometric analysis of chlorophylls and carotenoids from commonly grown fern species by using various extracting solvents. Res. J. Chem. Sci. 2014, 4, 63-69. 
71. Mayak, S.; Tirosh, T.; Glick, B.R. Plant growth-promoting bacteria that con-fer resistance in tomato to salt stress. Plant Physiol. Biochem. 2004, 42, 565-572. [CrossRef] [PubMed]

72. Lutts, S.; Kinet, J.M.; Bouharmont, J. NaCl-induced senescence in leaves of rice (Oryza sativa L.) cultivars differing in salinity resistance. Ann. Bot. 1996, 78, 389-398. [CrossRef]

73. Sadasivam, S.; Manickam, A. Biochemical Methods for Agricultural Sciences; Willey Eastern Limited: New Delhi, India, 1992.

74. Bates, L.S.; Waldren, R.P.; Teare, I.D. Rapid determination of free proline in water-stress studies. Plant Soil 1973, $39,205-207$. [CrossRef]

75. Nakano, Y.; Asada, K. Hydrogen peroxide is scavenged by ascorbate-specific peroxidase in spinach chloroplasts. Plant Cell Physiol. 1981, 22, 867-880.

76. Cakmak, I.; Marschner, H. Magnesium deficiency and high light intensity enhance activities of superoxide dismutase, ascorbate peroxidase, and glutathione reductase in bean leaves. Plant Physiol. 1992, 98, 1222-1227. [CrossRef]

77. Aebi, H.E. Catalase. In Methods of Enzymatic Analysis; Bergmeyer, H.U., Ed.; Verlag Chemie: Weinheim, Germany, 1983; pp. 273-286.

78. Roth, E.F.; Gilbert, H.S. The pyrogallol assay for superoxide dismutase: Absence of a glutathione artifact. Anal. Biochem. 1984, 137, 50-53. [CrossRef]

79. Blincoe, C.; Thiesen, M.O.; Stoddard-Gilbert, K. Sample oxidation procedures for the determination of chromium and nickel in biological material. Commun. Soil Sci. Plant Anal. 1987, 18, 687-697. [CrossRef]

80. Little, T.M.; Hills, F.J. Agricultural Experimentation: Design and Analysis; John Wiley and Sons, Ins.: New York, NY, USA, 1978.

81. Junaid, M.; Hashmi, M.Z.; Malik, R.N.; Pei, D. Toxicity and oxidative stress induced by chromium in workers exposed from different occupational settings around the globe: A review. Environ. Sci. Pollut. Res. 2016, 23, 20151-20167. [CrossRef]

82. Ruttens, A.; Mench, M.; Colpaert, J.V.; Boisson, J.; Carleer, R.; Vangronsveld, J. Phytostabilization of a metal contaminated sandy soil. I: Influence of compost and/or inorganic metal immobilizing soil amendments on phytotoxicity and plant availability of metals. Environ. Pollut. 2006, 144, 524-532. [CrossRef]

83. Ahmad, M.; Rajapaksha, A.U.; Lim, J.E.; Zhang, M.; Bolan, N.; Mohan, D.; Vithanage, M.; Lee, S.S.; Ok, Y.S. Biochar as a sorbent for contaminant management in soil and water: A review. Chemosphere 2013, 99, 19-33. [CrossRef] [PubMed]

84. Patra, J.M.; Panda, S.S.; Dhal, N.K. Biochar as a low-cost adsorbent for heavy metal removal: A review. Int. J. Res. Biosci. 2017, 6, $1-7$.

85. Cao, X.; Ma, L.; Gao, B.; Harris, W. Dairy-manure derived biochar effectively sorbs lead and atrazine. Environ. Sci. Technol. 2009, 43, 3285-3291. [CrossRef]

86. Rees, F.; Simonnot, M.O.; Morel, J.L. Short-term effects of biochar on soil heavy metal mobility are controlled by intra-particle diffusion and soil pH increase. Eur. J. Soil Sci. 2013, 65, 149-161. [CrossRef]

87. Lucchinia, P.; Quilliamc, R.S.; DeLucad, T.H.; Vameralia, T.; Jones, D.L. Does biochar application alter heavy metal dynamics in agricultural soil? Agric. Ecosyst. Environ. 2014, 184, 149-157. [CrossRef]

88. Nagarajan, M.; Ganesh, K.S. Effect of chromium on growth, biochemicals and nutrient accumulation of paddy (Oryza sativa L.). Int. Lett. Nat. Sci. 2014, 23, 63-71. [CrossRef]

89. Choudhury, S.; Panda, S.K. Toxic effects, oxidative stress and ultrastructural changes in moss Taxithelium nepalense (Schwaegr.) Broth. under chromium and lead phytotoxicity. Water Air Soil Pollut. 2005, 167, 73-90. [CrossRef]

90. Medda, S.; Mondal, N.K. Chromium toxicity and ultrastructural deformation of Cicer arietinum with special reference of root elongation and coleoptile growth. Ann. Agrar. Sci. 2017, 15, 396-401. [CrossRef]

91. Danish, S.; Kiran, S.; Fahad, S.; Ahmad, N.; Ali, M.A.; Tahir, F.A.; Rasheed, M.K.; Shahzad, K.; Li, X.; Wang, D.; et al. Alleviation of chromium toxicity in maize by Fe fortification and chromium tolerant ACC deaminase producing plant growth promoting rhizobacteria. Ecotoxicol. Environ. Saf. 2019, 185, 109706. [CrossRef]

92. Shahandeh, H.; Hossner, L. Plant screening for chromium phytoremediation. Int. J. Phytoremediation 2000, 2, 31-51. [CrossRef]

93. Mangabeira, P.A.; Ferreira, A.S.; de Almeida, A.A.; Fernandes, V.F.; Lucena, E.; Souza, V.L.; dos Santos, A.J., Jr.; Oliveira, A.H.; Grenier-Loustalot, M.F.; Barbier, F.; et al. Compartmentalization and ultrastructural alterations induced by chromium in aquatic macrophytes. Biometals 2011, 24, 1017-1026. [CrossRef]

94. Mei, B.; Puryear., J.D.; Newton, R.J. Assessment of Cr tolerance and accumulation in selected plant species. Plant Soil 2002, 247, 223-231. [CrossRef]

95. Pulford, I.; Watson, C.; McGregor, S. Uptake of chromium by trees: Prospects for phytoremediation. Environ. Geochem. Health 2001, 23, 307-311. [CrossRef]

96. Stanton, K.M.; Mickelbart, M.V. Maintenance of water uptake and reduced water loss contribute to water stress tolerance of Spiraea alba Du Roi and Spiraea tomentosa L. Hortic. Res. 2014, 33, 1-7. [CrossRef] [PubMed]

97. Wang, S.; Gao, B.; Li, Y.; Mosa, A.; Zimmerman, A.R.; Ma, L.Q.; Harris, W.G.; Migliaccio, K.W. Manganese oxide-modified biochars: Preparation, characterization and sorption of arsenate and lead. Bioresour. Technol. 2015, 181, 13-17. [CrossRef]

98. Jiang, J.; Xu, R.K.; Jiang, T.Y.; Li, Z. Immobilization of $\mathrm{Cu}(\mathrm{II}), \mathrm{Pb}(\mathrm{II})$ and $\mathrm{Cd}(\mathrm{II})$ by the addition of rice straw derived biochar to a simulated polluted Ultisol. J. Hazard. Mater. 2012, 229-230, 145-150. [CrossRef]

99. Mehmood, S.; Rizwan, M.; Bashir, S.; Ditta, A.; Aziz, O.; Yong, L.Z.; Dai, Z.; Akmal, M.; Ahmed, W.; Adeel, M.; et al. Comparative effects of biochar, slag and ferrous-Mn ore on lead and cadmium immobilization in soil. Bull. Environ. Contam. Toxicol. 2018, 100, 286-292. [CrossRef] [PubMed] 
100. Sabir, A.; Naveed, M.; Bashir, M.A.; Hussain, A.; Mustafa, A.; Zahir, Z.A.; Kamran, M.; Ditta, A.; Núñez-Delgado, A.; Saeed, Q.; et al. Cadmium mediated phytotoxic impacts in Brassica napus: Managing growth, physiological and oxidative disturbances through combined use of biochar and Enterobacter sp. MN17. J. Environ. Manag. 2020, 265, 110522. [CrossRef] [PubMed]

101. Nelson, D.L.; Cox, M.M. Lehninger Principles of Biochemistry, 4th ed.; Freeman: New York, NY, USA, 2004.

102. Adejumo, S.A.; Owolabi, M.O.; Owolabi, M.O. Agro-physiologic effects of compost and biochar produced at different temperatures on growth, photosynthetic pigment and micronutrients uptake of maize crop. Afric. J. Agric. Res. 2016, 11, 661-673. [CrossRef]

103. Asgher, M.; Per, T.S.; Verma, S.; Pandith, A.; Masood, A.; Khan, N.A. Ethylene supplementation increases PSII efficiency and alleviates chromium-inhibited photosynthesis through increased nitrogen and sulfur assimilation in mustard. J. Plant Growth Regul. 2018, 37, 1300-1317. [CrossRef]

104. Yruela, I. Copper in plants. Braz. J. Plant Physiol. 2005, 17, 145-156. [CrossRef]

105. Petrovi, J.; Nikoli, G.; Markov, D. In vitro complexes of copper and zinc with chlorophyll. J. Serb. Chem. Soc. 2006, 71, 501-512. [CrossRef]

106. Liu, D.; Zou, J.; Wang, M.; Jiang, W. Hexavalent chromium uptake and its effects on mineral uptake, antioxidant defense system and photosynthesis in Amaranthus viridis L. Bioresour. Technol. 2008, 99, 2628-2636. [CrossRef]

107. Mathur, S.; Kalaji, H.M.; Jajoo, A. Investigation of deleterious effects of chromium phytotoxicity and photosynthesis in wheat plant. Photosynthetica 2016, 54, 185-192. [CrossRef]

108. Singh, S.K.; Reddy, V.R.; Fleisher, D.H.; Timlin, D.J. Relationship between photosynthetic pigments and chlorophyll fluorescence in soybean under varying phosphorus nutrition at ambient and elevated $\mathrm{CO}_{2}$. Photosynthetica 2017, 55, 421-433. [CrossRef]

109. Gopal, R.; Rizvi, A.H.; Nautiyal, N. Chromium alters iron nutrition and water relations of spinach. J. Plant Nutr. 2009, 32, 1551-1559. [CrossRef]

110. Wang, Y.; Blatt, M.R. Anion channel sensitivity to cytosolic organic acids implicates a central role for oxaloacetate in integrating ion flux with metabolism in stomatal guard cells. Biochem. J. 2011, 439, 161-170. [CrossRef]

111. Chanda, S.V.; Parmar, N.G. Effects of chromium on hypocotyl elongation, wall components, and peroxidase activity of Phaseolus vulgaris seedlings. N. Z. J. Crop Hortic. Sci. 2003, 31, 115-124. [CrossRef]

112. Panda, S.K.; Choudhury, S. Chromium stress in plants. Braz. J. Plant Physiol. 2005, 17, 95-102. [CrossRef]

113. Rai, V.; Tandon, P.K.; Khatoon, S. Effect of chromium on antioxidant potential of Catharanthus roseus varieties and production of their anticancer alkaloids: Vincristine and vinblastine. BioMed Res. Int. 2014, 2014, 1-10. [CrossRef]

114. Paiva, L.B.; de Oliveira, J.G.; Azevedo, R.A.; Ribeiro, D.R.; da Silva, M.G.; Vitỏria, A.P. Ecophysiological responses of water hyacinth exposed to $\mathrm{Cr}^{3+}$ and $\mathrm{Cr}^{6+}$. Environ. Exp. Bot. 2009, 65, 403-409. [CrossRef]

115. Su, Y.; Han, F.X.; Sridhar, B.M.; Monts, D.L. Phytotoxicity and phytoaccumulation of trivalent and hexavalent chromium in brake fern. Environ. Toxicol. Chem. 2005, 24, 2019-2026. [CrossRef]

116. Shahid, M.; Pourrut, B.; Dumat, C.; Nadeem, M.; Aslam, M.; Pinelli, E. Heavy-metal-induced reactive oxygen species: Phytotoxicity and physicochemical changes in plants. Rev. Environ. Contam. Toxicol. 2014, 232, 1-44.

117. Shi, Y.; Huang, Z.; Liu, X.; Imran, S.; Peng, L.; Dai, R.; Deng, Y. Environmental materials for remediation of soils contaminated with lead and cadmium using maize (Zea mays L.) growth as a bioindicator. Environ. Sci. Pollut. Res. 2016, 23, 6168-6178. [CrossRef]

118. Zengin, F.K.; Munzuroglu, O. Effects of some heavy metals on content of chlorophyll, proline and some antioxidant chemicals in bean (Phaseolus vulgaris L.) seedlings. Acta Biol. Crac. Ser. Bot. 2005, 47, 157-164.

119. Cui, L.; Li, L.; Zhang, A.; Pan, G.; Bao, D.; Chang, A. Biochar amendment greatly reduces Cd uptake in a contaminated paddy soil: A two-year field experiment. Bioresources 2011, 6, 2605-2618.

120. Abbas, T.; Rizwan, M.; Ali, S.; Adrees, M.; Zia-ur-Rehman, M.; Qayyum, M.F.; Ok, Y.S.; Murtaza, G. Effect of biochar on alleviation of cadmium toxicity in wheat (Triticum aestivum L.) grown on Cd-contaminated saline soil. Environ. Sci. Pollut. Res. 2017, 26, 25668-25680. [CrossRef] [PubMed]

121. Rosa, M.; Prado, C.; Podazza, G.; Interdonato, R.; González, J.A.; Hilal, M.; Pradol, F.E. Soluble sugars-Metabolism, sensing and abiotic stress: A complex network in the life of plants. Plant Signal. Behav. 2009, 4, 388-393. [CrossRef]

122. Sinay, H.; Karuwal, R.L. Proline and total soluble sugar content at the vegetative phase of six corn cultivars from Kisar Island Maluku, grown under drought stress conditions. Int. J. Adv. Agric. Res. 2014, 2, 77-82.

123. Szabados, L.; Savoure, A. Proline: A multifunctional amino acid. Trends Plant Sci. 2010, 15, 89-97. [CrossRef]

124. Aly, A.A.; Mohamed, A.A. The impact of copper ion on growth, thiol compounds and lipid peroxidation in two maize cultivars (Zea mays L.) grown in vitro. Aust. J. Crop Sci. 2012, 6, 541-549.

125. Najafian, M.; Kafilzadeh, F.; Azad, H.N.; Tahery, Y. Toxicity of chromium $\left(\mathrm{Cr}^{6+}\right)$ on growth, ions and some biochemical parameters of Brassica napus L. World Appl. Sci. J. 2012, 16, 1104-1109.

126. Younis, U.; Malik, S.A.; Qayyum, M.F.; Shah, M.H.R.; Shahzad, A.N.; Mahmood, S. Biochar affects growth and biochemical activities of fenugreek (Trigonella corniculata) in cadmium polluted soil. J. Appl. Bot. Food Qual. 2015, 88, $29-33$.

127. Malook, I.; Rehman, S.U.; Khan, M.D.; El-Hendawy, S.E.; Al-Suhaibani, N.A.; Aslam, M.M.; Jamil, M. Heavy metals induced lipid peroxidation in spinach mediated with microbes. Pak. J. Bot. 2017, 49, 2301-2308. 
128. Saeed, Z.; Naveed, M.; Imran, M.; Bashir, M.A.; Sattar, A.; Mustafa, A.; Xu, M. Combined use of Enterobacter sp. MN17 and zeolite reverts the adverse effects of cadmium on growth, physiology and antioxidant activity of Brassica napus. PLoS ONE 2019, 14, e0213016. [CrossRef] [PubMed]

129. Foroozesh, P.; Bahmani, R.; Pazouki, A.; asgharzadeh, A.; rahimdabbagh, S.; Ahmadvand, S. Effect of cadmium stress on antioxidant enzymes activity in different bean genotypes. ARPN J. Agric. Biol. Sci. 2012, 7, 351-356.

130. Labudda, M.; Różańska, E.; Czarnocka, W.; Sobczak, M.; Dzik, J.M. Systemic changes in photosynthesis and reactive oxygen species homeostasis in shoots of Arabidopsis thaliana infected with the beet cyst nematode Heterodera schachtii. Mol. Plant Pathol. 2018, 19, 1690-1704. [CrossRef]

131. Hossain, M.A.; Piyatida, P.; da Silva, J.A.T.; Fujita, M. Molecular mechanism of heavy metal toxicity and tolerance in plants: Central role of glutathione in detoxification of reactive oxygen species and methylglyoxal and in heavy metal chelation. J. Bot. 2012, 2012, 1-37. [CrossRef]

132. Mourato, M.P.; Moreira, I.N.; Leitão, I.; Pinto, F.R.; Sales, J.R.; Martins, L.L. Effect of heavy metals in plants of the genus Brassica. Int. J. Mol. Sci. 2015, 16, 17975-17998. [CrossRef]

133. Chibuike, G.U.; Obiora, S.C. Heavy metal polluted soils: Effect on plants and bioremediation methods. Appl. Environ. Soil Sci. 2014, 2014, 1-12. [CrossRef]

134. Sharma, S.S.; Dietz, K.J.; Mimura, T. Vacuolar compartmentalization as indispensable component of heavy metal detoxification in plants. Plant Cell Environ. 2016, 39, 1112-1126. [CrossRef] [PubMed]

135. Shahid, M.; Shamshad, S.; Rafiq, M.; Khalid, S.; Bibi, I.; Niazi, N.K.; Dumat, C.; Rashid, M.I. Chromium speciation, bioavailability, uptake, toxicity and detoxification in soil-plant system: A review. Chemosphere 2017, 178, 513-533. [CrossRef]

136. Zayed, A.M.; Terry, N. Chromium in the environment: Factors affecting biological remediation. Plant Soil 2003, 249, 139-156. [CrossRef]

137. Oliveira, H. Chromium as an environmental pollutant: Insights on induced plant toxicity. J. Bot. 2012, 2012, 375843. [CrossRef]

138. Aldrich, M.V.; Gardea-Torresdey, J.L.; Peralta-Videa, J.R.; Parsons, J.G. Uptake and reduction of Cr(VI) to Cr(III) by mesquite (Prosopis spp.): Chromate-plant interaction in hydroponics and solid media studied using XAS. Environ. Sci. Technol. 2003, 37, 1859-1864. [CrossRef]

139. Das, A.P.; Mishra, S. Hexavalent chromium (VI): Environment pollutant and health hazard. J. Environ. Res. Dev. 2008, 2, 386-392.

140. Howe, J.A.; Loeppert, R.H.; Derose, V.J.; Hunter, D.B.; Bertsch, P.M. Localization and speciation of chromium in subterranean clover using XRF, XANES, and EPR spectroscopy. Environ. Sci. Technol. 2003, 37, 4091-4097. [CrossRef]

141. Tang, J.; Zhu, W.; Kookana, R.; Katayama, A. Characteristics of biochar and its application in remediation of contaminated soil: A review. J. Biosci. Bioeng. 2013, 116, 653-659. [CrossRef]

142. Park, J.H.; Choppala, G.K.; Bolan, N.S.; Chung, J.W.; Chuasavathi, T. Biochar reduces the bioavailability and phytotoxicity of heavy metals. Plant Soil 2011, 348, 439-451. [CrossRef]

143. Xu, R.K.; Xiao, S.C.; Yuan, J.H.; Zhao, A.Z. Adsorption of methyl violet from aqueous solutions by the biochar derived from crop residues. Bioresour. Technol. 2011, 102, 10293-10298. [CrossRef]

144. Inyang, M.; Gao, B.; Pullammanappallil, P.; Ding, W.; Zimmerman, A.R. Biochar from anaerobically digested sugarcane bagasse. Bioresour. Technol. 2010, 101, 8868-8872. [CrossRef] [PubMed]

145. Choppala, G.K.; Bolan, N.S.; Megharaj, M.; Chen, Z.; Naidu, R. The influence of biochar and black carbon on reduction and bioavailability of chromate in soils. J. Environ. Qual. 2012, 41, 1175-1184. [CrossRef] [PubMed]

146. Wang, X.; Wang, G.; Guo, T.; Xing, Y.; Mo, F.; Wang, H.; Fan, J.; Zhang, F. Effects of plastic mulch and nitrogen fertilizer on the soil microbial community, enzymatic activity and yield performance in a dryland maize cropping system. Eur. J. Soil Sci. 2021, 72, 400-412. [CrossRef]

147. Wang, X.; Fan, J.; Xing, Y.; Xu, G.; Wang, H.; Deng, J.; Wang, Y.; Zhang, F.; Li, P.; Li, Z. The effects of mulch and nitrogen fertilizer on the soil environment of crop plants. Adv. Agron. 2019, 153, 121-173. 